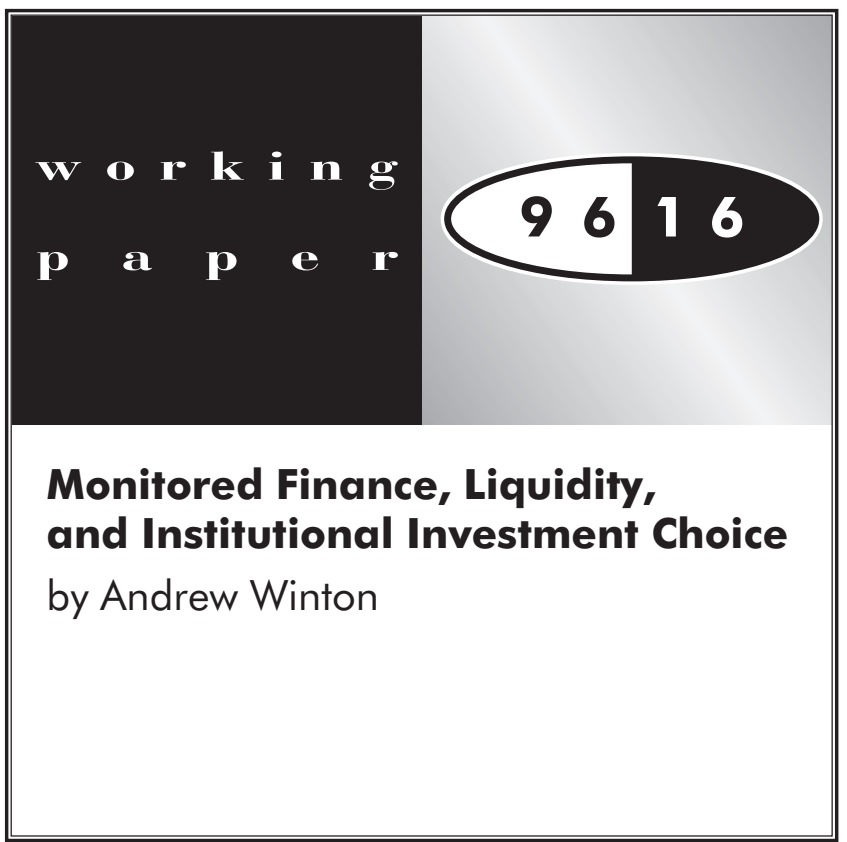




\title{
Monitored Finance, Liquidity, and Institutional Investment Choice
}

\author{
Andrew Winton \\ Finance Department \\ Northwestern University
}

\author{
This Version: October 1996
}

\begin{abstract}
When agency problems require that an financial institution monitor the firms that it finances, the private information that it gathers about these firms harms the institution's own liquidity. Dollar for dollar, debt is less risky and thus less sensitive to firm-specific information than equity, so holding debt improves the institution's liquidity. If only partial monitoring is necessary, lowered risk may reduce the institution's incentive to monitor, further improving its liquidity. However, if a firm's initial prospects are poor, debt with reduced monitoring may lead to excessive liquidation; here, if feasible, the firm's manager prefers equity with reduced monitoring. The preference for debt finance should be most pronounced for firms with limited access to public securities markets. Thus, the model predicts that debt or similar claims will dominate the portfolios of institutions that specialize in providing monitored finance. Among these institutions, those with greater liquidity needs should hold fewer monitored equity positions, make less risky loans, and monitor less intensively. These results are consistent with the general pattern of monitored finance and a number of cross-sectional institutional differences.
\end{abstract}

This research has been supported in part by a grant from the Banking Research Center and by a First Chicago Research Chair, both at Northwestern University. I am grateful to Peter DeMarzo, Laurie Hodrick, Mike Fishman, Kathleen Hagerty, Debbie Lucas, Mitch Petersen, and especially to Raghu Rajan for comments and advice. All mistakes remain my responsibility. 


\section{Introduction}

Monitoring and controlling agency problems that arise when firms use external finance is generally delegated to financial institutions, yet the institutions for whom this role is most essential-those that finance firms with limited access to public markets -- are lenders far more often than they are shareholders. ${ }^{1}$ If control is important, this pattern is somewhat puzzling. Although debt and equity each has its own channel of control, debt would seem the blunter instrument of the two. While a lender can declare a firm in default and seize its assets, default involves legal and other costs, the threat to force the firm into bankruptcy may not be credible, and the fixed charges associated with debt may distort the firm's investment decisions. By contrast, a majority equity stake gives close to unconditional power over the firm's assets, so equity should be more attractive to institutions that serve an active monitoring role.

I argue that, paradoxically, this monitoring role creates a preference for debt finance over equity. If institutions monitor, they are likely to have better information about the firms that they invest in than do other market participants. If such an institution is faced with a sudden need for funds ("liquidity needs"), it can react by either selling assets or issuing securities, but in either case it faces a "lemons" problem a la Akerlof (1970). This problem worsens as the institution's assets become more sensitive to its private information about its investments. Since, dollar-for-dollar, equity is generally riskier (and thus more sensitive to firm-specific information) than debt, and the institution requires a relatively large equity stake in order to exert control, an institution that focuses on equity investments suffers greater liquidity costs than one that focuses on debt investments. Such costs are passed through to the borrower in the form of a higher cost of capital, so all else equal, we should see a general preference for debt finance.

Liquidity issues complicate the institution's incentives to monitor in the first place. Monitoring not only improves the institution's control of borrower agency problems, but also increases the institution's information advantage when it decides whether to seek funding from uninformed market participants. Riskier claims are more sensitive to firm-specific information and increase this incentive to monitor. Ex ante, market participants know that the institution is more likely to have private information ex post, and the institution's adverse selection problem is further increased.

\footnotetext{
${ }^{1}$ For recent surveys of research on the role of agency problems in capital structure, see Harris and Raviv (1991) and Allen and Winton (1995). Diamond (1984), Ramakrishnan and Thakor (1984), and Boyd and Prescott (1986) are among the first to model financial institutions as delegated monitors; see also the survey by Bhattacharya and Thakor (1993).
} 
Debt finance may be even more attractive precisely because its lower risk can reduce the institution's incentive to monitor. If the firm only requires only a certain level of monitoring in order to obtain funds, additional monitoring may be wasteful, not only because of the direct cost of monitoring and the liquidity costs just mentioned, but because higher monitoring may increase the likelihood that the firm's manager will be deprived of nonpecuniary benefits of control. This last point is most likely to be a concern when the firm's owner is also its manager: the owner's goal is to raise enough money to fund the firm with the minimum outside interference and cost necessary.

Specifically, I assume that a firm's manager derives nonpecuniary benefits from running the firm, and will not voluntarily liquidate the firm even when an interim signal makes it clear that liquidation produces more cash than allowing the firm to continue. This problem must be at least partially overcome if the firm is to have any chance of repaying its investors, which in turn requires that at least one investor be given both control rights and the incentive to observe the costly interim signal (monitor) and make well-informed decisions about how to use these rights.

For a firm that is too small or too young to access public markets, most funding will come from such a monitoring institution. This means the institution bears a large share of the firm's risk, giving it strong incentives to monitor even when it holds debt; even so, it is generally optimal to give the institution a claim that emphasizes debt control (through the threat to withhold needed refinancing), because equity control requires greater exposure to the firm's risk and thus greater liquidity costs, which are passed through to the borrower. If the firm's required financing is relatively low, its cash flows are less risky, or its liquidation value is relatively high, reduced monitoring may be feasible and attractive for the reasons already discussed. Reduced monitoring is also more likely to be feasible if the institution's liquidity needs are relatively frequent or severe, since these factors reduce the institution's incentive to monitor so as to take advantage of market participants. Debt finance can reduce incentives to monitor, but if the firm's initial prospects are weak relative to its liquidation value, debt with reduced monitoring has too strong an incentive to liquidate the firm. In this case, the manager prefers equity finance if equity is compatible with reduced monitoring, and a higher level of debt finance with full monitoring otherwise.

A firm that can access public markets can get part of its funding from dispersed investors. One benefit is that these investors demand a lower liquidity premium: being too small to find monitoring worthwhile, they face less adverse selection when meeting their liquidity needs. The institution must still be given enough exposure to the firm's risk to make some monitoring incentive compatible, but 
the ability to reduce the institution's investment makes reduced monitoring more feasible. If the firm's initial prospects are weak relative to its liquidation value, access to public markets makes the firm more likely to give the institution a large equity stake; if prospects are strong, access to public markets makes the firm more likely to give the institution debt with lower risk.

In some ways this model is the mirror image of the Myers and Majluf (1984) "pecking-order" theory: there, a firm that needs funds and faces adverse selection prefers debt over equity forfunding; here, a firm that needs funds and faces adverse selection prefers debt over equity as aninvestment. Although one might argue that any firm might want to lower its asset risk for this reason, the risk of nonfinancial businesses is largely determined by industry, age, and other factors beyond their control, while financial institutions are in the business of choosing asset portfolios. Even if a financial institution's geographic and industry focus is to some extent set by its "core competencies," it can always alter its degree of risk through the types of claims it takes from borrowers.

My focus on liquidity helps explain why the active investor in this model is most naturally interpreted as a financial institution rather than a wealthy individual. Institutions are in the business of investing "other people's money," so raising funds on reasonable terms is of critical importance. Furthermore, institutions' role linking investors to borrowers means that their business creates liquidity needs on an ongoing basis: borrowers or securities issuers to finance, investor withdrawals to meet, and so forth. A wealthy individual may also have liquidity needs, but these are likely to be smaller and less frequent than the liquidity needs that an investment bank or commercial bank faces on a daily basis.

An alternative explanation for why many delegated monitors prefer debt over equity investments is that many of these institutions -- banks, finance companies, and insurers -- are highly levered compared to nonfinancial businesses; being riskier than debt, equity increases their risk of financial distress. While this is undoubtedly true, financial distress is a severe form of liquidity need. Moreover, this argument begs the question of why these institutions are so highly levered in the first place. One motivation is to combine my model with the "pecking order" theory: as delegated monitors with continuing needs for funds, liquidity problems loom large for these institution. Since debt is preferred as an external financing vehicle, these institutions end up being highly levered, which in turn creates a preference for debt over equity as an investment. Thus, rather than being a separate explanation for the predominance of lending over shareholding, risk control and leverage are directly linked to the same set of issues. 
By appealing to the basic function of financial institutions as delegated monitors, this model motivates a preference for lending by institutions whose asset choices are largely unregulated. For example, in the U.S., finance companies have no asset restrictions, yet they are overwhelmingly lenders or lessors. In Germany, until quite recently, banks and insurers had very few asset restrictions, yet they too are overwhelmingly lenders. Finally, private equity funds in the U.S. do hold and monitor private equity, yet this equity is predominantly preferred stock, and many of the control features associated with these investments resemble debt more than common stock?

In addition to being consistent with a general preference for ending by "delegated monitors," this model yields more specific predictions. Cross-sectionally, institutions that face more frequent or more severe liquidity needs should hold more monitored debt and less monitored equity in their portfolios; to the extent that they do hold equity, they should be more concentrated in the shares of larger well-known firms, where informational problems are less severe. Furthermore, the borrowers of institutions with higher liquidity needs should be less risky, since this reduces lemons costs and enhances the possibility of reduced monitoring. Finally, among institutions of a given type, larger ones should be more likely to hold large equity positions in firms, since these institutions are better diversified both against the chance of large-scale liquidity needs and against lemons problems in their own portfolios. (However, to the extent that some borrower risk is due to sectoral or systematic factors that are hard to pinpoint exactly, and organizational diseconomies of scale can harm monitoring quality, complete diversification against lemons problems is unlikely to be attainable.)

There is some stylized evidence that is consistent with these more specific predictions. For example, commercial banks have more short-term funding and specialize more in liquidity provision than do finance companies, and there is evidence that commercial bank loans are less risky and involve less intensive monitoring than those of finance companies. Pension funds and life insurers have longerterm funding than finance companies, and they hold relatively more equity, and more private equity in particular. The equity holdings of Germany's banks are overwhelmingly concentrated in the largest firms, and the largest banks (who have a minority share of all bank assets) account for most of these holdings.

As already noted, this paper focuses on the interaction between an institution's role as a

\footnotetext{
${ }^{2}$ See Section 7 below for specific institutional details and citations.

${ }^{3}$ Again, see Section 7 below.
} 
delegated monitor, the liquidity needs that the institution faces, and the structure of the financial claims that the institution holds. Three strands of previous research have touched on some of these issues: delegated monitoring in a setting of costly state verification, the liquidity of bank loans, and the allocation of seniority and maturity between bank lenders and other investors.

The costly state verification paradigm provides an alternative motivation for the prevalence of debt over equity. As shown in Gale and Hellwig (1985), debt contracts minimize an investor's expected costs of verifying a borrower's return. If multiple investors use an intermediary to verify borrower returns on their behalf, and the institution is sufficiently diversified across borrowers, the same logic makes it optimal for the institution to structure its investments as debt (see Williamson (1986), Krasa and Villamil (1992), and Winton (1995b)). Although the result that debt minimizes riskrelated costs is appealing, this relies on somewhat limiting technical assumptions. Moreover, the main cross-sectional prediction is that institutions with lower costs should always hold more junior claims, which is inconsistent with the preference of banks and finance companies for secured debt (see the discussions in Diamond (1993b) and Winton (1995a)).

Other researchers have examined the impact of a delegated monitor's private information about its assets on its behavior. Thus, Lucas and McDonald (1987, 1992) show that potential lemons problems may lead a bank to hold riskless securities as precautionary reserves, O'Hara (1993) investigates the impact of market value accounting on the maturity of bank loans, and DeMarzo and Duffie (1995) look at how an informed institution chooses to structure the securities it issues so as to minimize lemons costs. These papers do not model the institution's incentives to gather information, and to the extent the institution's assets are specified at all, they are assumed to take the form of debt.

Another strand of research examines the allocation of maturity and seniority to informed bank lenders vis-a-vis other uninformed investors. Diamond (1993a,b) shows that when a borrowing firm's manager receives unassignable control rents, the firm may issue a mix of short-term senior debt and long-term junior debt or equity so as to minimize unnecessary liquidation. If banks are better than other investors at observing the interim signal that triggers liquidation, they should hold the short-term

\footnotetext{
${ }^{4}$ The result that debt is optimal is weakened once renegotiation or randomized verification strategies are allowed -- see Gale and Hellwig (1989), Mookherjee and Png (1989), Krasa and Villamil (1994), and Persons (1995). Also, most delegated monitoring models use a single-period setting, which ignores the reality that many debt contracts are rolled over at maturity.

${ }^{5}$ In other related work, Greenbaum and Thakor (1987) and Pennacchi (1988) examine the link between a bank's monitoring decision and its use of loan sales or deposits as funding sources, and Stein (1995) examines how banks' private information about loans affects monetary policy.
} 
senior debt. Berlin, John, and Saunders (1996) show that having an informed bank hold both debt and equity can prevent the borrower and the bank from colluding to exploit uninformed creditors. While these three papers assume that the bank is costlessly informed, Park (1994) and Rajan and Winton (1995) examine the relationship between loan seniority and maturity on a bank's monitoring decision. These papers do not examine the liquidity implications of the institution's asset structure, and they largely apply to situations where the borrowing firm deals with many dispersed investors as well as the institution. ${ }^{6}$

The rest of the paper is organized as follows. Section 2 outlines the basic assumptions and framework of the model. Sections 3 and 4 assume that the institution is the firm's only source of funds; Section 3 takes the institution's claim structure as given and analyzes the institution's monitoring and control decisions and their interaction with its liquidity needs, while Section 4 analyzes the set of claims that the firm's manager issues to the institution in order to obtain funding. Section 5 discusses how the firm's ability to access public markets affects these results. Section 6 discusses additional considerations that might favor equity over debt. Section 7 discusses the model's empirical implications, some evidence that is consistent with these, and avenues for future research.

\section{Basic Model and Assumptions}

\section{A. The Firm}

A manager initially owns a firm that operates over three time periods -- 0,1 , and 2 . At time 0 , the firm requires an investment of I dollars. If the firm continues to operate until time 2 , it either succeeds, yielding a cash flow of $\mathrm{X}>\mathrm{I}$, or fails, yielding a cash flow of zero; in both cases, the value of the firm's other assets is assumed to be zero. If instead the firm is liquidated at time 1, its assets can be sold for L dollars, where $\mathrm{L}<\mathrm{I}$. The manager has no wealth beyond her initial ownership of the firm.

At time 0 , the probability that the firm will succeed is $q$, where $q$ is common knowledge. At time $1 \frac{1}{2}$ " (i.e., before time 1 but after time 0), anyone who is closely following ("monitoring") the firm gets a more precise signal of the firm's chance of success. For simplicity, assume that $\theta$ fully reveals whether the firm will fail or succeed; interpreting $\theta$ as the chance of success itself, it follows that $\theta$ equals 0 with probability $1-\mathrm{q}$ and 1 with probability q. Since the manager is closely involved

\footnotetext{
${ }^{6}$ Finally, Cabral dos Santos (1995) examines how a bank's (passive) debt and equity holdings affect borrower effort choice and thus the risk of the bank's deposits.
} 
with the firm's operations, she observes $\theta$ freely; others can only monitor and observe $\theta$ at a $\operatorname{cost} \mathrm{m}$. The decision to monitor must be made at time 0 , and the manager knows whether or not monitoring has occurred.

If she is still running the firm at the end of time 1, the manager receives nonpecuniary benefits that she values at $\mathrm{C}$. Thus, all else equal, she will not voluntarily liquidate the firm at time 1 unless she is compensated for losing $\mathrm{C}$, creating a possible agency problem with regard to the decision to liquidate or continue the firm's operations. For simplicity, I assume that the manager's control benefits $\mathrm{C}$ are greater than liquidation proceeds $\mathrm{L}$, so that the manager never voluntarily liquidates the firm.

Under these assumptions, the expected value of an unmonitored firm's cash flows is less than $\max \{\mathrm{qX}, \mathrm{L}\}--$ at best, the firm is either liquidated or continued uncondtionally. Assume that I exceeds $\mathrm{qX}$ as well as L, so that monitoring is necessary if the firm is to be financed.

If $\theta=0$, an investor who monitors the firm and has complete control and rights to all cash flows will liquidate the firm; if $\theta=1$, the firm will be allowed to continue and succeed. Thus, the investor's expected return is $(1-\mathrm{q}) \mathrm{L}+\mathrm{qX}-\mathrm{m}$. Assume that this exceeds $\mathrm{I}$, so that a monitored firm can be financed -- provided that the investor has sufficient control to overcome the manager's refusal to liquidate the firm. Since I exceeds $\max \{\mathrm{qX}, \mathrm{L}\}$, it follows that the cost of monitoring $\mathrm{m}$ is less than $(1-q) L+q X-\max \{q X, L\}$, which is the value of the option to either continue or liquidate the firm based on updated information rather than unconditionally doing one or the other.

\section{B. Financing Choices}

The manager can issue two securities: debt and equity. Debt has priority over equity and specifies a face value $\mathrm{D}$ that must be repaid at time 1 . If the debt is not repaid, the debtholder has the right to take control of the firm; otherwise, it is rolled over and must be repaid at time 2 . I use shortterm debt for simplicity; clearly, long-term debt without interim payments or covenants would have no means of control, which is the focus of this paper. (See Rajan and Winton (1995) for an analysis of the tradeoff between short-term debt and long-term debt with covenants.)

By contrast, equity is junior to debt and is specified by the fractionv of the firm's shares that an equityholder owns. If the equityholder controls more than $1 / 2$ of the firm's shares, she has control of the firm without any restriction or cost. If the equityholder controls a fraction $v<1 / 2$ of the shares, she can try to get the approval of other shareholders to bring her total to $1 / 2$; the cost is $s(1 / 2 \forall)$, where $s(0)=0$ and $s^{\prime}>0$. The intuition is that acquiring additional votes requires either a tender offer or a proxy fight, both of which involve additional costs that increase with the number of votes that need to 
be acquired.

When a controlling investor confronts the manager, the manager may try to renegotiate via a take-it-or-leave-it offer. It follows that the investor will accept any offer that has at least the same expected value as that which the investor would obtain by exercising control.

C. Investors

Investors come in two types, large and small. Large investors are financial institutions, while small investors can be either individuals or institutions making small investments in any given firm. Any large investor has sufficient wealth to finance the entire firm. Each small investor is infinitesimal, but in aggregate their wealth is also sufficient to finance the entire firm.

Since monitoring requires a significant fixed cost, only a large investor (henceforth, "institution") will monitor. For simplicity, assume that the manager chooses a single institution plus (possibly) a continuum of small investors to finance the firm, holding competitive auctions for each group. ${ }^{7}$

All investors are risk neutral and initially have zerotime preference. However, at time $1 / 2$, the institution has a probability $\lambda$ of experiencing a sudden need for funds (liquidity needs). When this occurs, the value of a dollar of time $1 / 2$ cash flows increases to $1+\beta(\beta>0)$, while the value of a dollar of later cash flows is unchanged at a dollar. This could represent a limited-time investment opportunity, a contractual take-down or withdrawal of funds by another customer, or perhaps a fullblown financial crisis; in all cases, failure to raise funds at time 1 could lead to either direct losses or opportunity costs for the institution. While $\lambda$ represents the probability of such liquidity needs, $\beta$ measures their severity (in terms of potential cost) when they occur.

Since small investors are uninformed, and most of the paper assumes that their investments can be distinguished from those of the institution, small investors suffer no lemons costs when they have liquidity needs. Section 5 discusses what happens when small investors' claims cannot be so distinguished.

Table 1 reviews the timing of events in the model.

\footnotetext{
${ }^{7}$ Multiple large investors could lead to duplication of effort and free rider problems in monitoring; still, there might be benefits if the different monitors' had imperfectly correlated information, or if monitoring quality was sufficiently convex in effort (see Winton (1993)). Also, if the effectiveness of control depended on the number of shares or amount of debt financing controlled, multiple large investors might gain from forming coalitions.
} 


\section{Financing With One Investor: The Institution's Behavior}

To fix the basic ideas, I focus on the case where the manager seeks financing from the institution alone. This section analyzes the institution's behavior in three steps. First, given its information and the set of financial claims that it holds, how does the institution exercise its control rights at time 1? Second, given the resulting payoffs to its claims and the possibility that it may have liquidity needs, how much financing does the institution raise at time $1 / 2$ ? Third, how does this time- $1 / 2$ financing behavior affect the institution's monitoring choice at time 0 ?

\section{A. The Institution's Exercise of Control Rights at Time 1}

Suppose that at time 1 the institution holds debt with face value D and and a fractionv of the firm's shares. The institution's use of its control rights is influenced by its information about the firm's situation, which can be summarized by the institution's estimate $\mathrm{p}$ of the firm's future chance of success. p has three possible values: if the institution has monitored the firm, it knows whether the firm will fail $(\mathrm{p}=0)$ or succeed $(\mathrm{p}=1)$, while if it has not monitored, it must rely on the prior probability of success $(p=q)$. Let $V(p, v, D)$ denote the expected value of the institution's cash flows given its information $\mathrm{p}$ and its financial claims $v$ and $\mathrm{D}$, assuming it acts optimally. Similarly, let $\mathrm{A}(\mathrm{p}, \mathrm{v}, \mathrm{D})$ denote the total expected value of cash flows and nonpecuniary control benefits produced by the firm when the investor's information is $\mathrm{p}$ and it holds D debt andv shares.

Lemma 1 (The Institution's Exercise of Control at Time 1). (i) Suppose that the institution knows that the firm will fail at time $2(\mathrm{p}=0)$. So long as the institution's debt holding is positive or it holds at least half the firm's shares, the firm will be liquidated at time 1 , so that

$$
\begin{array}{lll}
\mathrm{V}(0, v, \mathrm{D})= & \min [\mathrm{L}, v \mathrm{~L}+(1-\mathrm{v}) \mathrm{D}], & \text { if }>0 \text { or } v \geq 1 / 2, \\
0, & \text { otherwise. } \\
\mathrm{A}(0, v, \mathrm{D}) & \mathrm{L} & \text { if } \mathrm{D}>0 \text { or } v \geq 1 / 2, \\
\mathrm{C} & \text { otherwise. }
\end{array}
$$

(ii) Suppose that the institution knows that the firm will succeed at time $2(p=1)$. Then any debt is rolled over at time 1 and the firm will be allowed to continue: 


$$
\begin{array}{lll}
\mathrm{V}(1, v, \mathrm{D}) & =\quad v \mathrm{X}+(1-v) \mathrm{D} \\
\mathrm{A}(1, v, \mathrm{D}) & =\mathrm{X}+\mathrm{C}
\end{array}
$$

(iii) Suppose that the institution is uninformed $(p=q)$. Assuming that $(1+q) C$ exceeds L-qX, the manager will always offer as much cash as possible to prevent liquidation. It follows that

$$
\begin{array}{lll}
\mathrm{V}(\mathrm{q}, \mathrm{v}, \mathrm{D})= & \max \{\mathrm{V}(0, \mathrm{v}, \mathrm{D}), \mathrm{q} \cdot \mathrm{V}(1, \nu, \mathrm{D})\} \\
\mathrm{A}(\mathrm{q}, \mathrm{v}, \mathrm{D}) & \mathrm{A}(0, \mathrm{v}, \mathrm{D}) & \text { if } \mathrm{qX}<\mathrm{V}(0) \\
& \mathrm{qX}+\mathrm{C} & \text { if } \mathrm{qX} \geq \mathrm{V}(0)
\end{array}
$$

The proof is straightforward. If the firm will fail for certain (part (i)) and the institution has control, no offer that the manager can make will dissuade the institution from liquidating. Since the firm cannot refinance its debt, a positive debt level gives the institution control. Otherwise, the institution only has control if it owns at least half the firm's shares; all other shares are held by the manager, who will not agree to liquidate. An immediate consequence is that either the face value of debt D must exceed zero, or the institution's share of equity $v$ must exceed $1 / 2$. Otherwise, the total cash flows of a monitored firm are no greater than $\mathrm{qX}$, which by assumption is not enough to fund the investment.

If the firm will succeed for certain (part (ii)), the threat to liquidate the firm is never credible, since the firm (and thus the institution's claim) is certainly worth more if it is allowed to continue.

Finally, if the institution has not monitored (part (iii)) and it has sufficient control, it can liquidate the firm, in which case it would receive $\mathrm{V}(0, v, \mathrm{D})$. If the institution does not try to liquidate, the firm succeeds with probability q, and the institution's expected payment is $\mathrm{qV}(1, v, \mathrm{D})$. Since the manager can prevent the institution from liquidating by offering cash flows with expected value $\mathrm{V}(0, v, \mathrm{D})$, it follows that the institution receives the maximum of $\mathrm{V}(0, v, D)$ and $q \cdot V(1, v, D)$. The manager cannot offer more than $\mathrm{qX}$, so if $\mathrm{qX}$ is less than $\mathrm{V}(0, \mathrm{v}, \mathrm{D})$, the manager cannot prevent

\footnotetext{
${ }^{8}$ The manager cannot go to the market to refinance, since this will signal that the firm is about to fail. If the signal $\theta$ was noisy, or the firm's return in failure exceeded zero, low levels of debt could be refinanced, so liquidation would only result D exceeded some minimum level.
} 
liquidation; furthermore, $\mathrm{qX}$ exceeds $\mathrm{q} \mathrm{V}(1, \mathrm{v}, \mathrm{D})$, so the institution does liquidate, and the manager loses her control benefits. ${ }^{9}$

\section{B. The Institution's Liquidity Needs}

Recall that, at time $1 / 2$, the institution may have liquidity needs, so it may raise funds either by selling its claim or by issuing securities backed by its claim. If the institution sold its claim, it would not be able to exercise control over the firm afterwards, and the new owner of the claim would have to exercise control based on inferences about the firm's condition drawn from the fact of the sale. While this is an interesting problem, I defer it to later research. Issuing debt is another option, and might well be more attractive than issuing equity, since debt (being less risky) involves lower lemons costs; see DeMarzo and Duffie (1995) for some analysis of this issue. However, so long as the debt was risky, there would be lemons costs associated with seeking funding. Since modeling risky debt would complicate analysis without changing qualitative results, I assume that the institution meets any liquidity needs by issuing additional equity, creating a fraction $\phi$ of outside ownership of its position. ${ }^{10}$

The institution's choice of how much equity to issue depends on the relationship between the price the institution expects to receive, the claim's innate value based on the institution's information about the firm, and the institution's liquidity situation. Both the innate value and the institution's liquidity situation are private information. Note that, if the institution hasn't monitored, its knowledge that it has no private information about the firm is in itself private information.

Assume that the structure of the institution's claim on the firm $(v$ and D) is publicly known, and that investors who buy the institution's equity behave competitively. Then the price that the institution receives equals other investors' valuation of the claim on the firm, based on their beliefs about the institution's private information about the firm, and these beliefs in turn depend on the amount of equity issued. Thus, the choice of how much equity to issue is a signaling game, and equilibrium beliefs must be consistent with the institution's behavior based on its liquidity needs and

\footnotetext{
${ }^{9}$ Note that, if the institution doesn't have control, the firm is never liquidated and V(0y,D) equals zero, so the expressions in (3) are still correct.

${ }^{10}$ Here, since monitoring reveals the firm's future return with certainty, an institution that knew the firm would succeed could issue a large amount of riskless debt. This would not be the case in the more realistic situation where the institution's information was noisy and the institution had multiple assets. Furthermore, in a dynamic model, institutions that use debt for subsequent liquidity needs are likely to have used debt to obtain funds in the first place. This preexisting leverage would then heighten the risk of additional debt, increasing marginal lemons costs.
} 
its information about the firm.

Detailed analysis of this game can be found in Appendix A; what follows are highlights and intuition. Since the focus is now on the impact of the institution's information $p$ rather than the precise structure of its claim, I write $\mathrm{V}(v, \mathrm{D}, \mathrm{p})$ as $\mathrm{V}(\mathrm{p})$. An institution that knows the firm will do well $(\mathrm{p}=$ 1) is referred to as a "good" institution, while an institution that knows the firm will do badly $(\mathrm{p}=0)$ is referred to as "bad," and an institution that hasn't monitored $(\mathrm{p}=\mathrm{q})$ is referred to as "uninformed." Assume that the equilibrium probability that the institution hasn't monitored is $\alpha$.

All else equal, the equilibrium amount of equity that the institution issues is weakly higher if it has less favorable information about the firm, or if it has liquidity needs. Intuitively, the institution values a dollar at time $1 / 2$ at either $1+\beta$ or 1 , depending on whether or not it has liquidity needs, while a dollar at some later date is always worth a dollar. Since the future value of the institution's claim is $\mathrm{V}(\mathrm{p})$, the institution is just indifferent to issuing a share in this claim whenever the price of equity equals $\mathrm{V}(\mathrm{p})$ divided by $1+\beta$ or 1 as appropriate; if the price of equity is higher than this, the institution strictly prefers to issue equity at this price. Thus, the lower its "discounted" claim value, the greater the institution's willingness to issue equity. Liquidity needs or less favorable information (lower p) lower "discounted" value, increasing incentives to issue equity.

Suppose that the severity of liquidity needs is low, so that $1+\beta$ is close to 1 . Then, in equilibrium, a "good" institution will not pool with "worse" (uninformed or "bad") institutions; in fact, it will separate itself by issuing no equity at all. To see why, it suffices to focus on the motives of a good institution with liquidity needs -- one without liquidity needs has even less incentive to issue equity.

If the good institution issued an amount of equity that worse institutions might also choose, then the equity price $\mathrm{P}$ would be a weighted average of good and lower claim values, which must be strictly less than the good institution's innate claim value V(1). So long as the severity of liquidity needs $1+\beta$ is low enough, the institution's "discounted" claim value $V(1) /(1+\beta)$ is greater than the pooling price $\mathrm{P}$, and the good institution would rather not issue equity at all.

Suppose instead that the good institution tried to separate itself by issuing an amount of equity different from that chosen by worse institutions. If this was an equilibrium choice, other investors would realize that this must be the good institution and pay $\mathrm{V}(1)$ for the shares. Now consider the motives of an uninformed institution without liquidity needs. If it continues to issue an amount of equity different from that chosen by good institutions, it receives no more than $\mathrm{V}(\mathrm{q})$ for its shares; 
indeed, it may receive less if it pools with bad institutions. If the uninformed institution switches to issuing the same amount as the good institution, it receives $\mathrm{V}(1)$ on the shares it issues and eventually obtains $V(q)$ on the part of the claim that isn't refinanced, so it is strictly better off. Thus the good institution will be pooled with and receive strictly less than its "discounted" claim value, so it prefers to issue no equity at all.

Now look at the opposite extreme, when liquidity needs are very severe. Since $1+\beta$ is very high, the "discounted" claim value of a good institution with liquidity needs is very low. Rather than issue no equity and receive the innate value of its claim in the future, the good institution prefers to issue a lot of equity and get cash now, even if it pools with worse institutions and receives a low price for its equity. It is easy to show that it is now an equilibrium for all institutions with liquidity needs to issue the maximum amount of equity (for simplicity, a fraction $\phi$ equal to one). A bad institution without liquidity needs will join in issuing the maximum amount, since the pooling price has to be higher than its innate value $\mathrm{V}(0)$; a good institution without liquidity needs will prefer to separate by issuing no shares (with no liquidity benefit from issuing shares, such an institution never pools with worse ones).

If an uninformed institution without liquidity needs also pools by issuing the maximum amount of equity, I call this equilibrium the "maximum-pooling equilibrium." The pooling price is

$$
P_{M}(\alpha)=\frac{\alpha(1-q) V(0)+(1-\alpha) V(q)+\alpha q \lambda V(1)}{1-\alpha q(1-\lambda)}
$$

which is simply the expected value of the institution's claim across all types that issue equity. I write the price as a function of $\alpha$, since it depends on the probability $\alpha$ that the institution is uninformed. It follows that an uninformed institution without liquidity needs will want to pool whenever its claim value $V(q)$ is no more than $P_{M}(\alpha)$; since $P_{M}(\alpha)$ is a weighted average of $V(q)$ and $P_{M}(1)$, this is equivalent to $V(q)$ being no more than $P_{M}(1)$. (Note that this condition always holds if the value of an uninformed institution's claim $V(q)$ equals that of a bad institution $V(0)$.) Otherwise, the uninformed institution without liquidity needs separates by issuing little or no equity.

In general, more severe liquidity needs (higher $1+\beta$ ) make pooling more possible, but matters are more complex for intermediate levels of liquidity needs. Pooling by all institutions with liquidity needs may be impossible, yet semipooling outcomes may exist and dominate the separating outcome. In order to simplify analysis, I require that buyers' equilibrium beliefs satisfy the D1 refinement of Cho and Kreps (1987) and Banks and Sobel (1987). D1 restricts the beliefs that buyers have when they 
see a level of equity being issued that is not the supposed equilibrium choice of some type of institution. ${ }^{11}$

D1 implies that, whenever the value of an uninformed institution's claim $\mathrm{Vq}$ ) is less than the "discounted" claim value $\mathrm{V}(1) /(1+\beta)$ of a good institution with liquidity needs, good institutions separate from bad institutions by issuing no equity. Here, rgardless of liquidity needs, good institutions always have the highest "discounted" claim values, and D1 beliefs allow them to break any pooling outcome by issuing somewhat less equity. By contrast, once $V(q)$ weakly exceeds $V(1) /(1+\beta)$, there is usually some pooling between good institutions with liquidity needs and bad institutions. Pooling by all institutions with liquidity needs is now possible when either an uninformed institution's claim value $\mathrm{V}(\mathrm{q})$ is less than $\mathrm{P}_{\mathrm{M}}(1)$ (as discussed above), or when a bad institution's value $\mathrm{V}(0)$ exceeds the "discounted" claim value $\mathrm{V}(1) /(1+\beta)$ of a good institution with liquidity needs.

To summarize, when liquidity needs $(1+\beta)$ are low relative to the impact of the institution's information about its claim's value $(\mathrm{V}(1)$ relative to $\mathrm{V}(\mathrm{q})$ or $\mathrm{V}(0))$, institutions with higher-quality claims separate by issuing no equity: they would rather wait and get the true value of their claims, even though they get no cash to help with current liquidity needs. By contrast, when liquidity needs are high relative to the impact of information, good institutions prefer to pool rather than separate.

When it exists, the maximum-pooling equilibrium dominates all other equilibria (including separating equilibria) on an ex-ante basis. While this may seem counterintuitive, the reasoning is simple. Here, when contracting and monitoring take place, the institution does not know what type (good or bad) its claim will eventually prove to be. Even though pooling involves an ex-post crosssubsidy from good institutions to bad ones, this would not affect an institution's ex-ante return ifall types (including good institutions without liquidity needs) pooled. Since good institutions without liquidity needs never pool, there is always some loss: some of the cross-subsidization by the good institution with liquidity needs goes to the bad institution without liquidity needs. Still, on average, the institution receives more cash when liquidity needs strike by pooling, since separating means getting

\footnotetext{
${ }^{11} \mathrm{D} 1$ requires that buyers that see an out-of-equilibrium equity level $\phi^{\prime}$ focus their beliefs on the types most likely to make that deviation; an equilibrium "meets" the refinement if it is supported by such beliefs. Lemma A.2 of Appendix A shows that, of the types that are supposed to issue less than $\phi^{\prime}$ in equilibrium, the type with the most incentive to deviate to $\phi^{\prime}$ is the one with the lowest discounted claim value; similarly, of the types that are supposed to issue more than $\phi^{\prime}$, the type with the most incentive to deviate to $\phi^{\prime}$ is the one with the highest discounted claim value. Under D1, buyers that see $\phi^{\prime}$ believe that the issuer is one of these two types.
} 
no cash at all if the claim proves to be good. The problem is that, ex post, pooling may not be incentive compatible.

Liquidity needs introduce state dependence into the institution's preferences which it would like to insure against. Unfortunately, by the time it seeks financing, it may be better informed about its assets, creating an adverse selection problem. The end result is that, as in Hirshleifer (1971), information revelation interferes with optimal ex-ante insurance. On the other hand, this information is valuable, since it improves the precision of the institution's control over agency problems with the firm's manager. This tradeoff between information's value-enhancing and liquidity-reducing roles is the key point of the paper.

\section{The Institution's Investment and Monitoring Decisions at Time 0}

At time 0 , the institution must decide whether to invest in the firm and, if so, whether to monitor. Both decisions must take into account the institution's later actions in dealing with any liquidity needs and in exercising control over the firm. As this subsection shows, the need to give the institution incentive to invest and monitor significantly restricts the set of equilibria under which the firm can be financed.

Let $\mathrm{M}(v, \mathrm{D})$ be the institution's expected return from investing in $v$ shares and $\mathrm{D}$ debt, monitoring the firm, and then behaving optimally given its information about the firm. Similarly, let $\mathrm{N}(v, \mathrm{D})$ be the institution's expected return from investing in $v$ shares and $\mathrm{D}$ debt, not monitoring, and then behaving optimally given its lack of information about the firm. If the institution didn't invest in the firm, it could keep I dollars on hand to meet any subsequent liquidity needs, so that its ex-ante utility would be $(1+\lambda \beta) \cdot$ I. Thus, the institution invests only if

$$
\mathrm{M}(v, \mathrm{D}) \geq(1+\lambda \beta) \cdot \mathrm{I}
$$

which is its individual rationality constraint. If the institution invests, it only monitors if

$$
M(v, D) \geq N(v, D)
$$

which is its incentive compatibility constraint. If (IC) holds strictly, it strictly prefers monitoring over not monitoring; otherwise, it is indifferent and may monitor with probability $\alpha$ less than one.

$\mathrm{M}(v, \mathrm{D})$ and $\mathrm{N}(v, \mathrm{D})$ depend on the equity-issuance equilibrium, which in turn depends on the 
relationships between $\mathrm{V}(0), \mathrm{V}(\mathrm{q}), \mathrm{V}(1)$, and $1+\beta$. Even with $\mathrm{D} 1$ beliefs, multiple equilibria may be possible. The following analysis generally assumes that, if multiple equilibria exist, the ex-ante dominant one is chosen. ${ }^{12}$ All proofs are given in Appendix B.

Proposition 2 (Feasible Equilibria).

(i) Suppose that either (a) $V(q)<V(1) /(1+\beta)$, or

(b) $\mathrm{V}(\mathrm{q})>\mathrm{V}(1) /(1+\beta)>\mathrm{V}(0)$ and $\mathrm{V}(\mathrm{q})>\mathrm{P}_{\mathrm{M}}(1)$.

Then, if investment occurs, the institution monitors with certainty $(\alpha=1)$, and there is separation between good institutions, who issue no equity, and bad institutions, who issue the maximum amount. The institution's expected return is

$$
\mathbf{M}(\boldsymbol{v}, \mathrm{D})=(1-q
$$

(ii) Suppose that either (a) $V(0)>V(1) /(1+\beta)$ and $V(q)>P_{M}(1)$, or

(b) $\mathrm{V}(\mathrm{q})>\mathrm{V}(1) /(1+\beta)$, and $\mathrm{V}(\mathrm{q}) \leq \mathrm{PM}(1)$.

Then, if investment occurs, the maximum-pooling equilibrium is feasible, and $M(v, D)$ is given by

$$
M(\nu, D)=[1-q(1-\lambda)+\lambda \beta] \cdot P_{M}(\alpha)+q(1-\lambda) \cdot V(1)-(1+\lambda \beta) \cdot m .
$$

If (a) holds, or (b) holds but $\mathrm{P}_{M}(1)<\mathrm{I}$, then monitoring occurs with certainty $(\alpha=1)$. Otherwise, monitoring may be random $(\alpha<1)$, in which case (IC) holds with equality and can be written as

$$
q(1-\lambda)\left[V(1)-P_{M}(\alpha)\right]=(1+\lambda \beta) m \text {. }
$$

Again, increasing the severity of liquidity needs $1+\beta$ relative to the impact of information $V(1) / V(q)$ or $V(1) / V(0)$ makes pooling easier to support. ${ }^{13}$ Since the impact of information is directly related to the risk of the institution's claim, reducing this risk is one way to promote pooling.

The proposition also shows that less-than-certain ("reduced") monitoring requires pooling with

${ }^{12}$ The one exception is in the case of Proposition 2(i.b): here, a partially-pooling equilibrium may exist that ex-ante dominates the separating equilibrium. In this other equilibrium, bad institutions with liquidity needs issue the maximum amount of equity, while others issue a lower amount $\phi$ that leaves the bad type with liquidity needs indifferent between issuing $\phi$ and issuing the maximum amount. This equilibrium does not alter the paper's qualitative results, so I ignore it for simplicity.

${ }^{13}$ Pooling is also easier to support when an uninformed institution's claim value $V(q)$ is no more than the pooling price (with certain monitoring) $P_{M}(1)$. When $V(q)$ equals $V(0)$, this is always true; otherwise, it is equivalent to the condition that $\mathrm{q}(1-\lambda) \mathrm{V}(1)$ is no more than $\mathrm{V}(0)$, which is more likely the higher $\mathrm{V}(0)$ is relative to $\mathrm{V}(1)$. 
a sufficiently high pooling price. A separating equilibrium cannot support reduced monitoring because an uninformed institution receives no more than its claim's value $\mathrm{V}(\mathrm{q})$ times $1+\lambda \beta$; since unmonitored firms cannot be funded, this is less than $(1+\lambda \beta) \cdot \mathrm{I}$, and individual rationality then requires that monitoring must be strictly preferred to not monitoring. The only way an uninformed institution can do better than $(1+\lambda \beta) \cdot V(q)$ is in a pooling equilibrium where the pooling price exceeds $V(q)--$ that is, the uninformed institution must be able to profit by imitating a good institution. If this pooling price exceeds the required investment $\mathrm{I}$, then it is possible to both satisfy individual rationality and have the institution be indifferent between monitoring and not monitoring.

A necessary condition for a sufficiently high pooling price is that the required investment $\mathrm{I}$ is less than $\mathrm{P}_{\mathrm{M}}(1)$, the pooling price assuming certain monitoring. Riskier firms are less likely to meet this condition; intuitively, monitoring is more attractive for riskier investments because the institution's ex post information advantage over uninformed market participants is higher for riskier investments. $^{14}$

Finally, suppose reduced monitoring is feasible. Then increases in the probability $\alpha$ of monitoring make investment more attractive ((IR) is more likely to hold) and monitoring less attractive ((IC) is less likely to hold). Intuitively, the uninformed institution pools and receives a price in excess of its claim's value $\mathrm{V}(\mathrm{q})$, so reducing the chance $1-\alpha$ that the institution is uninformed increases the pooling price. This increases the return to monitoring, making investment more attractive, but increases the return to not monitoring (where the institution issues equity for certain) even more, making monitoring less attractive.

${ }^{14}$ Suppose that the spread between the maximum cash flow $\mathrm{X}$ and the liquidation value $\mathrm{L}$ is increased while the firm's (maximum) expected cash flow (1-q) $\mathrm{L}+\mathrm{qX}$ and probability of success $\mathrm{q}$ are both held constant. Then increasing $X$ by $d X$ implies $L$ must decrease by-(q/(1-q))dX. By contrast, $\mathrm{P}_{\mathrm{M}}(1)$ is bounded above by $[(1-\mathrm{q}) \mathrm{L}+\mathrm{q} \lambda \mathrm{X}] /[1-\mathrm{q}(1-\lambda)]$, so $\mathrm{P}_{\mathrm{M}}(1)>\mathrm{I}$ requires $\mathrm{L}>\mathrm{I}-(\mathrm{q} \lambda /(1-\mathrm{q}))(\mathrm{X}-\mathrm{I})$. Increasing $X$ by $d X$ means this bound on $L$ decreases by $-(q \lambda /(1-q)) d X$, which is slower than $-q /(1-q)$. 


\section{Financing With One Investor: The Manager's Choice of Contracts at Time 0}

The overall goal of the analysis is the optimal mix of debt and equity that the manager issues to the institution at time 0 . The previous section showed that this mix determines the institution's use of control rights (and thus the values of $\mathrm{V}(0), \mathrm{V}(\mathrm{q})$, and $\mathrm{V}(1)$ ), which in turn determines the equilibrium outcome of the institution's equity-issuance game at time $1 / 2$. Thus, the manager's optimal financing mix is that which leads to the feasible equilibrium outcome that the manager most prefers.

This section analyzes the optimal financing mix and equilibrium outcome in four steps. First, how does the manager's objective function depend on the institution's equilibrium behavior? Second, when are separating or pooling equilibria feasible? Third, if reduced monitoring is not feasible, what is the optimal mix? Finally, when is reduced monitoring feasible, and how does this affect the optimal mix?

For simplicity, assume that the manager makes a take-it-or-leave-it offer to the institution (or takes competitive bids from many institutions). The manager's goal is to maximize the sum of her expected control benefits and the firm's expected cash flows, net of the required investment I and payments to the institution. Note that the institution pays $M(\nu, D) /(1+\lambda \beta)$ for its claims, since each dollar invested today has an opportunity cost $1+\lambda \beta$; if this exceeds $I$, the manager keeps the difference.

\section{Proposition 3 (Manager's Objective Function).}

(i) If the manager chooses $v$ and $\mathrm{D}$ that lead to a separating equilibrium, her objective function is

$$
\mathrm{E}(\nu, \mathrm{D})=(1-\mathrm{q}) \mathrm{L}+\mathrm{q}(\mathrm{X}+\mathrm{C})-\mathrm{I}-\mathrm{m}-\frac{\dot{\lambda} \beta}{1+\lambda \beta} \mathrm{q} \cdot \mathrm{V}(1)
$$

(ii) If the manager chooses $v$ and $\mathrm{D}$ that lead to a pooling equilibrium, her objective function is

$$
E(\nu, D)=(1-q) L+q(X+C)-I-m-\frac{\lambda \beta}{1+\lambda \beta} q(1-\lambda)\left[V(1)-P_{M}(1)\right]
$$

if monitoring occurs with certainty $(\alpha=1)$, and 


$$
E(\nu, D)=\alpha \cdot[(1-q) L+q(X+C)]+(1-\alpha) \cdot A(q, \nu, D)-I-\alpha m-\alpha \lambda \beta m,
$$

if monitoring occurs with probability less than one $(\alpha<1)$.

The intuition is straightforward. If the institution has monitored, the firm's expected cash flows and control benefits total $(1-q) L+q(X+C)$; if the institution is uninformed, these equal $A(q, v, D)$ as derived in Lemma 1. The required investment I must be netted from this amount, as well as the difference between total expected payments to the institution and the amount that the institution invests in the first place. Since the manager captures all surplus, this last difference equals expected monitoring costs $\alpha \mathrm{m}$ plus any liquidity costs that the institution incurs.

In the separating equilibrium, the institution is unable to obtain any cash when it observes the good state, so its expected liquidity losses equal $q \cdot V(1)$ times the "liquidity premium" $\lambda \beta /(1+\lambda \beta)$. In the pooling equilibrium, the institution always issues equity when faced with liquidity needs, as do bad institutions without liquidity needs. Since the good institution without liquidity needs doesn't pool, and this occurs with probability $\alpha q(1-\lambda)$, the pooling price is less than the claim's average value by $\alpha q(1-\lambda)$ times $\left[\mathrm{V}(1)-\mathrm{P}_{\mathrm{M}}(\alpha)\right]$; multiplying by $\lambda \beta /(1+\lambda \beta)$ equals expected liquidity losses. If the institution only monitors part of the time, equation (7) from Proposition 2(ii) shows that these losses equal $\alpha \lambda \beta \mathrm{m}$; otherwise, incentive compatibility may not be strictly binding, and losses are no less than $\lambda \beta \mathrm{m}$. Thus, as equilibrium moves from separating to pooling to pooling with reduced monitoring, liquidity costs decrease: pooling dominates separation, and reducing the probability of monitoring makes it less likely that the institution is informed, reducing the adverse selection that it faces.

As shown in Proposition 2, equilibrium moves towards pooling (and pooling with reduced monitoring) as the risk of the institution's claim decreases. Furthermore, in any given type of equilibrium, expected liquidity costs tend to increase with the risk of the institution's claim: in the separating equilibrium, these are linked $\mathrm{V}(1)$ (which can be decreases by increasing $\mathrm{V}(0)$, all else equal); in the pooling equilibrium with certain monitoring, these are linked to $\mathrm{V}(1)-\mathrm{P}_{\mathrm{M}}$, which equals $\mathrm{V}(1)-\mathrm{V}(0)$ times a constant; in the pooling equilibrium with reduced monitoring, these are linked to $\alpha$, which decreases as the institution bears less of the firm's risk. Thus, reducing the risk of the institution's claim reduces liquidity costs both directly and by favoring less costly types of equilibria. 
The next step in the analysis is to determine when separa ting and pooling equilibria are feasible. As a start, define $V s$ as the minimum level of $V(1)$ (i.e., the smallest payment to the institution in the good state) that meets the institution's individual rationality constraint in a separating outcome, and $V_{P}$ as the minimum level of $V(1)$ that meets the institution's individual rationality constraint in a maximum pooling outcome, assuming that the institution monitors with certainty $(\alpha=$ 1). Since (ceteris paribus) a decrease in $V(1)$ requires an increase in $V(0)$, it follows that these levels can be obtained by setting $\mathrm{V}(0)$ equal to $\mathrm{L}$ and then solving the (IR) constraint as an equality. Because these payments give the institution as much as possible in the bad state and as little as possible in the good state, these payment schemes have the lowest risk of all feasible schemes in separating and pooling equilibria. The following lemma provides explicit formulas and comparative statics for these two payment levels.

Lemma 4. (i) Define Vs and $\mathrm{Vp}$ as above. Then

$$
\begin{gathered}
V_{s}=\frac{1+\lambda \beta}{q} \cdot[1+m-(1-q) L] \\
V_{p}=\frac{1+\lambda \beta}{q} \cdot\left[1+m-(1-q) L \cdot\left(\frac{1+\frac{\lambda \beta}{1-q(1-\lambda)}}{1+\lambda \beta}\right)\right] \cdot\left[1+\frac{\lambda^{2} \beta}{1-q(1-\lambda)}\right]^{-1},
\end{gathered}
$$

and $V_{p}<V_{s}$.

(ii) $V_{s}$ and $V_{P}$ are increasing in the required investment $I$, the cost of monitoring $m$, and the severity $B$ of the institution's liquidity needs. They are decreasing in the firm's liquidation value $L$ and the firm' $s$ probability of success q. Vs is increasing in the institution's probability $\lambda$ of having liquidity needs.

All else equal, the minimum payment that supports the separating equilibrium is higher than that for the pooling equilibrium because separation involves higher liquidity costs. Increases in required investment, monitoring costs, or liquidity needs all increase the minimum payment that the institution needs to break even; by contrast, increases in the firm's liquidation value reduce necessary payments when the firm succeeds, as do increases in the firm's likelihood of success.

Although Lemma 4 identifies the minimum payments to the investor that are compatible with 
individual rationality in separating and pooling equilibria, it does not address incentive compatibility. For example, even setting $\mathrm{V}(0)$ equal to $\mathrm{L}$ and $\mathrm{V}(1)$ equal to $\mathrm{V}_{\mathrm{P}}$, the institution's claim may be so risky that only separation is possible; alternatively, the institution's risk may be so low that it doesn't have incentive to monitor in a pooling equilibrium. The next proposition addresses both individual rationality and incentive compatibility, determining the optimal choice of equilibrium and financing mix in those situations where reduced monitoring is not feasible.

\section{Proposition 5 (Manager's Choice of Financial Structures With Certain Monitoring).}

(i) If $V_{P}$ exceeds $X$, it is impossible to support investment in equilibrium.

(ii) Suppose that either (a) $\max \left\{q \cdot V_{P}, L\right\}<V_{P} /(1+B)$, or

(b) $q \cdot V_{P}>V_{P} /(1+\beta)>L$, and $q(1-\lambda) V_{P}>L$.

Then if $V_{s}>X$, it is impossible to support investment in equilibrium. If $V_{s} \leq X$, the manager's optimal choice is to issue a mix of debt $D$ and equity $v$ such that $D$ exceeds $L$ and $v X+(1-v) D$ equals $\mathrm{Vs}_{\mathrm{s}}$; in equilibrium, the institution separates, and monitors with certainty. Conditions (a) and (b) are more likely as the cost of monitoring $\mathrm{m}$ or the firm's required investment $\mathrm{I}$ is higher, as the firm's liquidation value $L$ or probability of success $q$ is lower, or as the severity B of the institution's liquidiity needs is lower.

(iii) Suppose $V_{P}$ is no more than $X$, and neither (ii.a) nor (ii.b) hold. If

$$
\mathrm{m} \leq \frac{(1-q)(1-\lambda)}{\lambda(1+\lambda \beta)} \cdot(I-L)
$$

then the manager issues a mix of debt $\mathrm{D}$ and equity $v$ such that $\mathrm{D}$ exceeds $\mathrm{L}$ and $v \mathrm{X}+(1-v) \mathrm{D}$ equals $V_{P}$. In equilibrium, the institution pools, and monitors with certainty. Condition (13) is more likely to hold as the probability $\lambda$ or severity $\beta$ of the institution's liquidity needs is lower, as the cost of monitoring $\mathrm{m}$ or the firm's probability of success is lower, or as the difference I-L between required investment and liquidation proceeds is higher.

Since separation involves higher liquidity costs, the manager chooses a separating outcome only if pooling with certain monitoring cannot be sustained. Since pooling is less likely as the relative risk of the institution's claim $\mathrm{V}(1) / \mathrm{V}(0)$ increases, and this cannot be less than $\mathrm{V} / \mathrm{L}$, factors that increase this ratio relative to $1+\beta$ make the separating outcome more likely. Intuitively, increasing the cost of monitoring or the firm's required investment increase the institution's required payments in good states and thus the risk of its claim. Decreasing the firm's liquidation value or chance of success has similar effect. Although decreasing the severity of the institution's liquidity needs decreases its required payments and thus the risk of its claim, the institution's incentive to pool decreses even faster; intuitively, payments reflect expected liquidity needs (which occur with probability $\lambda$ ), while the 
pooling condition reflects a liquidity that has actually arrived and thus looms larger.

When the conditions in (i) and (ii) don't hold, setting the institution's payment in the good state to $V_{P}$ (and thus setting its payment in the bad state to L) will be individually rational and will sustain a pooling equilibrium at time $1 / 2$ so long as the institution monitors in the first place. Condition (13) guarantees that the institution has sufficient incentive to monitor. In this case, only monitoring with certainty is feasible: any other set of individually rational claims must involve a greater spread between good and bad payments $\mathrm{V}(1)$ and $\mathrm{V}(0)$, which only increases the institution's incentive to monitor. Condition (13) is more likely to hold as the risk of the institution's claim increases, which is why the firm's characteristics affect this condition in the same way that they affected the likelihood of a separating outcome. Decreases in the probability or severity of the institution's liquidity needs decrease expected liquidity costs of monitoring, so the informational advantage that monitoring gives the institution when it decides whether or not to issue equity is more attractive. Finally, monitoring is clearly more attractive as its cost decreases. This last result shows that monitoring costs can have a nonmonotone effect on the equilibrium intensity of monitoring: low costs lead to pooling with full monitoring, high costs lead to separation with full monitoring, while intermediate costs may allow pooling with reduced monitoring.

In all cases where investment is feasible and certain monitoring results, the manager chooses a mix of financing that gives the institution as much as possible in the bad state and as little as possible in good states. In these situations, the institution's behavior with regard to liquidation is fixed, so the manager's only concern is to reduce liquidity costs by reducing the institution's risk as much as possible.

When condition (13) doesn't hold, reduced monitoring may be feasible: now, setting $\mathrm{V}(0)$ equal to $\mathrm{L}$ and $\mathrm{V}(1)$ equal to $\mathrm{V}_{\mathrm{P}}$ doesn't give the institution incentive to monitor with certainty, so increasing the institution's payments needn't result in certain monitoring. The next question is, does the manager want reduced monitoring?

Proposition 6 (Manager's Choice of Monitoring Level). Suppose that conditions (i-iii) in Proposition 5 do not hold, so that reduced monitoring may be feasible.

(i) If $\mathrm{qX} \geq \mathrm{L}$, then the manager prefers to set monitoring as low as possible.

(ii) If $\mathrm{qX}<\mathrm{L}$, then if, setting $\mathrm{V}(0)=\mathrm{qX}$, it is possible to set $\mathrm{V}(1)$ to support pooling and reduced monitoring $(\alpha<1)$ by the institution, the manager chooses this with monitoring $\alpha$ as low as possible. Otherwise, the manager sets monitoring as high as possible in any pooling equilibrium. 
As already noted, reducing the probability of monitoring has the benefit of reducing the institution's liquidity costs, which are linked to its private information. Also, the manager always wants to prevent liquidation when possible, because she values control $\mathrm{C}$ more than liquidation proceeds L. In part (i) of Proposition 6, qX exceeds the liquidation value $\mathrm{L}$, so, as per Lemma 1, the manager can always buy off an uninformed institution and prevent liquidation. In this case, reducing the probability of monitoring (and thus of liquidation) always benefits the manager, although she is bound by the constraint that the firm must be liquidated with some probability if financing is to be found.

In part (ii), $\mathrm{qX}$ is less than $\mathrm{L}$, and the manager can only convince an uninformed investor to allow the firm to continue (saving control benefits) if $\mathrm{V}(0)$ is no more than $\mathrm{qX}$. Setting $\mathrm{V}(0)$ to $\mathrm{qX}$ may not be feasible because individual rationality restricts how low the institution's payment in the bad state can be. Also, the lower is $\mathrm{V}(0)$, the higher is $\mathrm{V}(1)$; this increases incentives to monitor and reduces incentives to pool, both of which work against reduced monitoring. ${ }^{15}$ In part (i), these concerns don't apply; setting $\mathrm{V}(0)$ equal to $\mathrm{L}$ makes pooling most feasible and makes individual rationality easiest to meet, so the manager unambiguously prefers to set debt levels relatively high.

Having set $\mathrm{V}(0)$, the manager wants to set $\mathrm{V}(1)$ high enough so that both incentive compatibility and individual rationality hold. Recall from the discussion following Proposition 2 that increasing monitoring $\alpha$ makes individual rationality more likely to hold. It can also be shown that, holding $\mathrm{V}(0)$ constant, increasing $\mathrm{V}(1)$ increases the monitoring probability $\alpha$ consistent with incentive compatibility; intuitively, higher risk increases the institution's incentive to monitor. Thus, if she wants low monitoring, the manager sets $\mathrm{V}(1)$ high enough to just meet individual rationality; otherwise (when $\mathrm{qX}$ is less than $\mathrm{L}$ and $\mathrm{V}(0)$ equal to $\mathrm{qX}$ is infeasible), she increases $\mathrm{V}(1)$ until $\alpha=1$ is reached. ${ }^{16}$

To summarize the results on the manager's choice of financial contracts, unles qX is less than $\mathrm{L}$, the manager prefers to give the institution all of the firm's proceeds when it fails $(\mathrm{V}(0)=\mathrm{L})$,

\footnotetext{
${ }^{15}$ Also, with a mix of debt and equity, $\mathrm{V}(0)=\mathrm{qX}<\mathrm{L}$ limits $\mathrm{V}(1): \mathrm{V}(0)=\mathrm{L}+(1-v) \mathrm{D}$, so (1-v)D $=\mathrm{qX}-\mathrm{vL}$ and $v \leq \mathrm{qX} / \mathrm{L}$; then $\mathrm{V}(1)=v \mathrm{X}+(1-\mathrm{v}) \mathrm{D} \leq(\mathrm{qX} / \mathrm{L})(\mathrm{X}-\mathrm{L})+\mathrm{qX}=(\mathrm{qX} / \mathrm{L}) \mathrm{X}$.

${ }^{16}$ However, higher V(1) may cause pooling to break down before $\alpha=1$ is reached. If individual rationality does not hold at this lower $\alpha$, only a separating equilibrium is feasible. Otherwise, the manager must choose between reduced monitoring and the separating equilibrium.
} 
regardless of whether the final equilibrium is separating, pooling, or pooling with reduced monitoring. This is also true if $\mathrm{qX}$ is less than $\mathrm{L}$ and the conditions in either (ii) or (iii) of Proposition 5 hold, since in these circumstances reduced monitoring is not feasible. This can be supported by setting $\mathrm{D}=\mathrm{V}(1)$ and $v=0$, or by setting $\mathrm{D}=\mathrm{L}$ and $v=[\mathrm{V}(1)-\mathrm{L}] /[\mathrm{X}-\mathrm{L}]$, or any number of interior combinations; however, if more than two return states were possible, the all debt structure would be strictly preferred.

The only case in which a debt level of L or more may not be chosen is when conditions (i-iii) in Proposition 5 don't hold and qX is less than L. Now, if feasible, the manager may wish to set the institution's payment $\mathrm{V}(0)$ equal to $\mathrm{qX}$ or less. This immediately implies that a larger part of the investor's claim takes the form of equity; however, if $\mathrm{qX}$ is less than $1 / 2 \mathrm{~L}$, the institution's sharev will be less than $1 / 2$, and so once more control will have to be exercised through debt. Also, the lower is $\mathrm{qX}$ relative to $\mathrm{L}$, the more likely that $\mathrm{V}(0)$ equal to $\mathrm{qX}$ is infeasible or doesn't support pooling.

The upshot is that pure equity control is only chosen for firms where ex ante prospects are lower than liquidation value, but not too low. If ex ante expected cash flows are very low relative to liquidation values, or liquidation values themselves are too low, full monitoring is required, and firms will choose debt-like finance; if ex ante expected cash flows are higher than liquidation values, firms choose debt finance with reduced monitoring.

The analysis also suggests that the institution will play a more active monitoring role when the firm's risk is high (e.g., I-L is high, or the probability of success is low), since this makes separating equilibria more likely and, even when pooling is possible, makes reduced monitoring less feasible. Similarly, institutions with lower likelihood or severity of liquidity needs (lower $\lambda$ or $\beta$ ) are better suited to play an active monitoring role and better suited to take on riskier firms. Turning this around, active monitors have more need to reduce their likelihood of severe liquidity needs, or, failing that, to reduce the risk of the claims that they hold -- which may involve seeking out less risky firms to invest in. 


\section{Funding With Multiple Investors}

The analysis thus far suggests a strong preference for debt finance, or at least for a financing package that uses debt at least as high as the firm's liquidation value. On the other hand, the analysis has assumed that the manager raises funds from a single investor. This section discusses the manager's incentives to raise funds from multiple investors, focusing as previously noted on the case of one large and many small investors. Implicitly, this assumes that the firm's characteristics are already wellknown or can be transmitted to large numbers of small investors at relatively small cost.

Suppose that the manager issues D debt and $v$ shares as before, but now these are split in some fashion between the institution and small investors. For simplicity, asssume that all debt has the same priority, and that free-rider problems and fixed costs prevent small investors from exercising control in an active way (although they can refuse to roll over their debt). The sequence of events is unchanged.

Allowing additional investors relaxes the individual rationality constraint on the institution. Since this constraint was binding upon the institution in parts (i-iii) of Proposition 5, in these situations it may now be feasible to reduce the institution's stake in the firm significantly without violating incentive compatibility. Since this reduces the liquidity costs of the institution without affecting its monitoring decision, this unambiguously helps the manager. In terms of specific financing choices, the manager benefits by reducing the institution's payment in success $V(1)$ from $V_{s}$ or $V_{P}$ to a level that just meets the incentive compatibility constraint under certain monitoring, while leaving the institution's payment in the bad state at L; this can be accomplished by issuing enough equity to small investors to make up the difference, reducing overall liquidity costs. (Once again, setting $\mathrm{V}(0)$ to $\mathrm{L}$ minimizes $\mathrm{V}(1) / \mathrm{V}(0)$ for any given difference $\mathrm{V}(1) \mathrm{V}(0)$, increasing the odds of a pooling equilibrium.)

A further consequence is that reduced monitoring is more likely to be feasible. In Proposition 2 , reduced monitoring was ruled out in a separating equilibrium or a pooling equilibrium with low pooling price because reduced monitoring requires indifference between monitoring and not monitoring, and the institution couldn't meet the individual rationality constraint if it was uninformed. Another way of looking at this is that, when it provides all of the firm's financing, the institution bears much of the firm's risk. This leads the institution to prize monitoring "excessively" from the viewpoint of the manager, who effectively pays for the liquidity costs linked to the institution's private information, and who values nonpecuniary control benefits that do not enter into the institution's 
calculations. ${ }^{17}$

When the firm's ex ante cash flows from continuation dominate liquidation ( $\mathrm{qX}$ exceeds $\mathrm{L}$ ), reduced monitoring is attractive, and can be accomplished by leaving $\mathrm{V}(0)$ at $\mathrm{L}$ and reducing $\mathrm{V}(1)$ even further. Thus, for "basically successful" firms, debt finance with relatively low risk is even more dominant when large numbers of additional investors can be brought in and given equity.

When the firm's ex ante cash flows from liquidation dominate continuation ( $q X$ is less than $\mathrm{L}$ ), the manager may wish to reduce $\mathrm{V}(0)$ to $\mathrm{qX}$ as discussed in Section 3. There are two reasons why additional investors make this more feasible than before. First, individual rationality is less binding. Second, by giving some debt to the small investors, the institution can be given a claim that is worth only $\mathrm{qX}$ in the bad state and yet represents a fraction of equity close to $1 / 2$. Indeed, ifv $=1 / 2$ involves too much risk (and liquidity costs) for the institution, she can be given a somewhat smaller fraction, allowing her to win over small shareholders at cost $s(v-1 / 2)$.

Thus, introducing additional investors who free ride on the institution's decisions reduces the institution's share in the firm's risk, reducing information-linked liquidity costs that are passed through to the manager, and possibly reducing monitoring as well. The one catch is that the institution must have incentive to make appropriate choices based on its information; multiple investors can make this harder to meet because the institution's smaller stake makes it easier for the manager to bribe it into allowing excessive continuation. Although in principle the small investors could be given veto power over changes in financial structure, this right might be quite costly to enforce with large numbers of small investors.

In this model, such collusion won't occur so long as the investor has monitored: if the institution knows the firm will certainly fail, it cannot be bribed; if the firm will certainly succeed, the manager has no need for bribery.$^{18}$ If the institution has not monitored and liquidation provides higher overall cash flows than continuation $(\mathrm{V}(0) \leq \mathrm{qX}<\mathrm{L})$, such collusion is an issue. As noted in the discussion following Proposition 6, this may actually be beneficial if the manager wishes to reduce the level of monitoring, but monitoring and liquidation must be high enough to make investment feasible,

${ }^{17}$ Diamond (1993a,b) also introduces junior claimants to prevent excessive liquidation, but does not model monitoring incentives. In Pagano and Roell (1996), large minority shareholders can monitor to deprive the majority shareholder of control benefits; as in this model, introducing small shareholders reduces "excessive" monitoring.

${ }^{18}$ As previously noted, the manager's ability to bribe the institution would increase if the institution's information was less precise $\left(\theta_{1}>0\right)$. 
and this limits how small the institution's claim can be. ${ }^{19}$

To summarize, for firms where, ex ante, continuation is more profitable than liquidation, the desire to give the institution debt is reinforced: the institution gets $\mathrm{L}$ in the bad state and an amount in the good state that is high enough to achieve the manager's desired level of monitoring. For firms where, ex ante, liquidation is more profitable, the firm is now more likely to be able to give the institution equity so as to achieve the benefits of reduced monitoring without "excessive" liquidation.

\section{Considerations That May Favor Equity Control Over Debt Control}

A more subtle reason for the general dominance of debt over equity in this model is that I have assumed that the only agency problem facing investors is excessive continuation -- a problem that debt is well-suited to deal with. Indeed, control through equity alone requires a riskier claim for any given dollar amount of investment, which tends to increase liquidity costs, and the higher risk may lead to "excessive" monitoring. Nevertheless, there are good reasons for thinking that equity control has some advantages that debt control lacks. This section discusses five such reasons, all widely discussed in the literature: costs associated with transferring control to debtholders, other managerial agency costs, the possibility that a large shareholder may receive an information advantage over a large debtholder, information benefits from public securities markets, and separation of ownership and control. ${ }^{20}$

Costs of transferring control to debtholders. While a majority shareholder may have full power to decide a firm's actions, a debtholder only receives this power when the firm defaults on its debt obligation -- a right which is then enforceable through the courts. Even leaving aside the American bankruptcy system's well-known tendency to reduce creditor rights, a court-overseen process is likely to involve at least some delay and legal costs, which may also lead to indirect costs. For example, if transfer of control takes too long, the most profitable liquidation opportunities may have disappeared.

Since these costs are likely to be greater when more claimants (especially creditors) are involved, they should have the least effect when the firm is financed by a small number of investors, as in the case of smaller or younger firms that find it too costly to access public markets. Thus, these

${ }^{19}$ The presence of small investors imposes an additional constraint: if the risk of the institution's claim is low enough, and it has control, it may unconditionally liquidate the firm rather than monitor. (This is not an issue when the institution is the sole source of funds, since its investment is at least I, which exceeds the liquidation value L.) See Rajan and Winton (1995) for analysis of this constraint.

${ }^{20}$ A number of relevant references can be found in Harris and Raviv's (1991)'s review article on capital structure. 
firms are most likely to bear out the results of the single-investor case, where debt control tends to dominate. Also, to the extent more investors can be brought in, it may be better to reduce the institution's individual rationality constraint by bringing in many small shareholders rather than many small debtholders, leaving the institution with debt control without increasing control-transfer costs too much. Finally, firms with a high chance of failure (low q) are more likely to use equitycontrol so as to avoid transfer costs.

Other managerial agency problems. In addition to the problem of excessive continuation, managers may waste valuable resources on pet projects, perquisites, and empire-building; indeed, such concerns have been offered as a major motive for the takeover wave of the 1980s.

In the context of this model, suppose that the manager receives an additional non-pecuniary control benefit $\mathrm{C}$ for operating the firm through the end of time 2 , and that, if she learns that the firm is going to be successful, she can also divert up to X-Y of future cash flows into perquisites, etc., leaving $\mathrm{Y}$ for investors. At the beginning of time 2, investors with control can prevent the diversion by replacing the manager. The new manager does not have time to set up new pet projects, so the firm yields $\mathrm{X}$, and the old manager loses her control benefit $\mathrm{C}$ for the end of time 2 as well as any gain from diversion.

An institution that monitors can exercise control and fire the manager when diversion begins. If the institution has a large equity stake, it can do this directly (at some cost, if it doesn't control a majority of shares). If the institution relies on debt for control and sees diversion taking place, it can demand repayment of its debt, take control, and replace the manager, but this threat is only credible if the debt can't be refinanced elsewhere and if allowing diversion hurts the institution. Both considerations suggest that the institution' claim on the firm must either involve some equity or a debt level greater than Y. Knowing this, the manager refrains from diverting resources to the point at which the institution has no incentive to intervene. However, if there any costs of transferring control, the manager will divert an additional amount equal to these costs, leaving the institution indifferent to intervening, and in a stochastic model, actual deadweight costs would be incurred with some probability. ${ }^{21}$

21 This can be viewed as a reduced-form of a model where a successful firm's cash flows vary randomly between $\mathrm{Y}$ and $\mathrm{X}$ and are hard to verify, so that the manager can stochastically divert cash flows above Y. Also, if replacing the manager had direct costs, equilibrium would probably involve mixed strategies in both diversion and firing. 
Thus, using debt to control diversion has two drawbacks: debt transfer costs are incurred with high probability, and the debt level must be very high, making the debt risky and illiquid. These are less likely to concern the entrepreneurial firms modeled here: since the owner is the manager, any diversion accrues to her, and since she only wishes to raise enough money to meet the firm's required investment level, it may be possible to do this while still diverting some of the "upper tail" of the firm's returns.

This problem also complicates the owner's desire for reduced monitoring. If the institution has not monitored, it can still exercise control rights unconditionally, i.e., fire the manager at the start of time 2 regardless. This behavior makes reduced monitoring less attractive to the manager, and is more likely when the institution has a majority of shares and faces no cost of obtaining control.

Information advantages conveyed by large equity stakes. Many have argued that, by allowing "easy" access to management or even a seat on the board, large shareholdings give an investor cheaper and more precise information than does debt alone. To some extent, this may be endogenous: equity bears more risk than debt, so shareholders have more incentive to monitor the firm intensively. Still, the threat of discipline from a large shareholder may make management more forthcoming, and a seat on the board commits one to hearing regular reports from management.

Suppose that having a significant equity stake (say, greater than somev ${ }^{*}<1 / 2$ ) does give the institution better information: if the institution has less than $v^{*}$ shares, then even if it monitors it remains uninformed some fraction of the time. Clearly, an institution that monitors can make better informed decisions if it has more than $v^{*}$ shares, but this better information also increases the adverse selection problem that faces an institution with liquidity needs; also, better information makes monitoring more cost-efficient, which can lead to "too much" monitoring and liquidation from the manager's perspective. Thus, paradoxically, improved information for large shareholders may reinforce some of the benefits of debt finance: lower liquidity costs, and lower incentive to monitor "excessively."

Information benefits from public markets. Publicly-traded firms benefit from improved public information, through both disclosure requirements and information revealed by trading activity. Since this narrows the gap between public information and the private information of the institution, the institution faces less adverse selection when it seeks financing, decreasing its liquidity costs. This should make holding large equity positions in firms less onerous. Thus, to the extent that institutions with significant liquidity concerns do hold large equity blocks, they are more likely to be concentrated 
in large publicly-traded firms -- precisely what one finds for Germany's universal banks.22

Separation of ownership and control. A key assumption in this paper has been that the firm's initial owner is also its manager, yet the ownership of many large corporations is diffuse, with management holding a relatively small fraction of shares. All else equal, this should increase the importance of control benefits over cash flows in the manager's objective function. Larger firms may also generate substantial internal funds, lessening their need for external finance of any sort; such firms would tend to prefer dispersed ownership and finance through retained earnings.

On the other hand, if there is an active market for corporate control, objectives may be reversed, with cash flows mattering more than control benefits. This makes equity control more attractive, since it can squeeze as much cash as possible from the upper as well as lower tails of the firm's return distribution. However, for a large firm, obtaining funding from a single institution may be prohibitively expensive. LBOs are a way of dealing with this problem: most of the financing comes from risky debt, making it easier for the LBO fund to hold a concentrated equity stake. Although much of the debt comes from institutions such as banks that do some monitoring, the primary monitor is the LBO fund, whose finance is structured to reduce liquidity needs (see the discussion of private equity finance below).

\section{Implications}

This paper's results deal with both the nature and amount of highly monitored finance sought by firms and the portfolio composition of the financial institutions that provide the monitoring. Smaller or younger firms that rely on funding from a relatively small group of investors should generally prefer monitored finance that is largely debt or which has strong debt-like features in terms of risk and control channels. For firms with access to public markets, the advantage of monitored debt finance should decrease, and monitoring should be less intense. Among firms of a given size, those that have greater risk of poor returns, lower liquidation values, or higher required investments should have riskier financing (either higher debt levels or debt with some equity "kicker") and should experience higher monitoring activity, both of which will make the monitored claims that these firms issue less liquid.

${ }^{22}$ One caveat is that, if the institution holds publicly-traded shares and learns that the firm is in bad shape, it may sell its shares rather than intervene to improve firm performance. Holding restricted shares (as implicitly assumed here) reduces this problem, since these cannot be traded anonymously. See Kahn and Winton (1996) for an analysis of these issues. 
Although some of these results are not unique to this particular model of firm funding choice, combining them with the liquidity dimension of the analysis leads to strong predictions about institutional portfolio composition. The more likely or more severe an institution's liquidity needs are, the greater the desirability of reduced monitoring; however, this may not always be feasible, depending on firm characteristics. As a result, there should be sorting among firms that seek informationallyintensive financing, with riskier firms and firms with relatively high investment needs seeking institutions with lower liquidity pressures; similarly, among institutions that actively monitor firms, those with higher liquidity needs should favor debt more in their asset portfolios.

Furthermore, an institution's chance of severe liquidity needs $(\lambda$ in the model) is somewhat endogenous. If an institution's funding exposes it to high liquidity needs, it can reduce the fraction of extremely information-sensitive assets in its portfolio, so that most liquidity needs can be met by selling or issuing financing against other less illiquid holdings. Similarly, by lengthening and spreading its funding maturities, an institution can reduce the size of liquidity needs caused by the need to refinance itself. Finally, to the extent larger institutions are better diversified, a given investment's illiquidity is of less harm to the institution, increasing its ability to take on risky illiquid investments; however, the caveat is that monitoring may be harder to motivate as the institution becomes larger and more diffuse.

These implications are consistent with a number of stylized facts.

Private equity vs. private debt. As noted, firms that lack access to public markets should rely more heavily on debt or debt-like finance. In fact, Fenn et al. (1995) estimate that, in the U.S., total private equity of the type described in this paper (i.e., from outside investors) was $\$ 100$ billion. By contrast, based on the Flow of Funds, private corporate debt was much higher, including $\$ 750$ billion bank loans, $\$ 300$ billion in net finance company loans, over $\$ 600$ billion privately-placed bonds, and $\$ 670$ billion in commercial mortgages..$^{23}$ Furthermore, the private equity typically resembles a hybrid of debt and equity, as detailed at the end of this section.

Most of this private equity is concentrated in two groups: venture capital, which focuses on start-ups with high but risky growth potential, and non-venture finance, which is more concentrated on middle-market firms (see Fenn et al. (1995)). Although Small Business Investment Companies do

\footnotetext{
${ }^{23}$ For privately-placed debt, the distribution of public vs. private bonds given by Carey et al. (1993) for outstanding bonds in 1992 is applied to total corporate bond outstandings for 1994. Also, the private equity total here does not include direct investments in real estate; however, for insurers and banks, available data suggests that this figure is a small fraction of real-estate-related loans.
} 
provide finance to small businesses that don't attract venture capital, their equity investment accounts for less than $\$ 1$ billion of the $\$ 100$ billion total estimated by Fenn et al.. Thus, with few exceptions, small businesses must rely on loans rather than equity.

General portfolio composition for levered financial institutions. Since commercial banks, life insurers, and finance companies are highly levered (averaging roughly $90 \%$ debt to assets in the U.S.), risk and liquidity concerns should lead them to strongly prefer debt over equity as monitored assets. Although regulation restricts the asset choices of U.S. banks and insurers ${ }^{24}$ U.S. finance companies are unregulated and still prefer debt: based on the 1994 Flow of Funds, 30\% of assets are mortgages and consumer loans, $45 \%$ are business loans and leases. The balance sheets of GMAC and GE Capital Services (two of the largest finance companies) suggest that few of the remaining assets are equity.

In Germany, banks and insurers have generally had few regulatory limits on their equity holdings, yet these institutions' equity holdings are dwarfed by their private debt holdings. ${ }^{26}$ In 1991 , German banks had DM 5,574 billion in assets; of these, only 27 billion (or less than .5\%) were equities and participation rights, as opposed to 3,336 billion (60\%) in loans to non-banks. (Since these figures reflect book values rather than current market values, the role of equity is certainly greater than this suggests; still, as noted below, German banks only hold a small percentage of all shares, so debt still predominates.) Life insurers had DM 584 billion in investments; of these, only 23 billion (4\%) were shares, and only 34 billion (6\%) were direct real estate holdings, as opposed to 85 billion (15\%) in bonds, 277 billion (47\%) in nonmortgage loans, and 87 billion (15\%) in mortgage loans. Institutional shareholdings focus mostly on large firms: Saunders and Walter (1994) report that in 1989 , German banks held only .6\% of all industrial firm's shares, but roughly $5 \%$ of the top 100

${ }^{24}$ U.S. banks cannot purchase equity in nonfinancial firms, and bank holding companies are restricted to small passive equityholdings (see Carey et al. (1993)); however, banks can actively hold equity for as long as ten years if it is received as part of a workout (see James (1995)), and bank holding company subsidiaries can be active equityholders (see Fenn et al. (1995)). Life insurers can hold up to $20 \%$ of their portfolios in equity investments, but only $5 \%$ can be invested actively, i.e., where the insurer has significant control (see Roe (1994)).

${ }^{25}$ In 1994, GE Capital Services reported \$2 billion equity investments out of \$31 billion total investments (the rest being debt), and $\$ 76$ billion net financing receivables. GMAC reported $\$ .5$ billion equity investments, $\$ 4$ billion total investments, and $\$ 55$ billion net financing receivables.

${ }^{26}$ In addition, the universal banks have the ability to vote the proxies for shares which they hold in trusts or on behalf of their brokerage customers (see Edwards and Fisher (1994)). 
firms' shares. ${ }^{27}$

Cross-sectional differences among institutional portfolios. The model suggests that institutions with longer-term financing should hold relatively more equity, all else equal. For example, life insurers have longer-term funding than do banks or finance companies, so life insurers should hold more equity than these other institutions. Similarly, pension funds also have long-term financing and are less likely than insurers to allow some form of early withdrawal or policy loans, so they should hold the most equity. This pattern holds in the U.S., although regulation of banks and insurers clouds the issue. ${ }^{28}$

A comparison of commercial banks and finance companies provides additional support for the model's predictions. Both types of institutions provide relatively short-term financing to borrowers. However, their funding structures differ: banks are much more in the business of liquidity provision, offering demand deposits and credit lines, and much of their remaining funding is extremely short-term (Federal funds and Eurodollar deposits with maturities under two weeks); by contrast, finance companies obtain roughly one third of their funding from commercial paper and other short-term sources, another third from long-term debt, and have somewhat lower leverage ratios Federal Reserve Bulletin, various issues). On the asset side, finance companies have a higher fraction of loans and lower fraction of cash than banks; also, Carey, Post, and Sharpe (1996) find that finance company loans are riskier than bank loans, and present anecdotal and qualitative evidence that finance companies monitor their loans more closely than banks. This is consistent with the prediction that institutions with higher (exogenous) liquidity needs should monitor less heavily and make less risky loans.

Finally, larger institutions should be better diversified against liqudity concerns and should hold greater amounts of equity as a fraction of assets. Consistent with this, Edwards and Fischer (1994) report that, in 1975, the "Big Three" universal banks of Germany accounted for $41 \%$ of all German bank shareholdings, while in 1980 these banks accounted for only $12.5 \%$ of all nonmortgage

\footnotetext{
${ }^{27}$ Also, in a sample of 86 German IPOs between 1970 and 1988, Goergen (1995) finds that on average, banks owned only $3 \%$ of voting shares pre-IPO, while insurers accounted for less than $1 \%$; these percentages did not increase markedly during the five years following the IPO.

${ }^{28}$ Thus, based on the 1994 Flow of Funds, private pension funds held $44 \%$ of their assets in corporate equities, life insurers held $8 \%$, and commercial banks held less than $2 \%$. The same pattern emerges for private equity holdings, where liquidity issues are presumably greatest: public pension funds held $\$ 23$ billion in private equity ( $2 \%$ of their total assets), private pension funds held $\$ 20$ billion (1\%), life insurers held \$7 billion (.4\%), and commercial banks held $\$ 11$ billion (.3\%). See Fenn et al. (1995) and the 1994 Flow of Funds.
} 
loans (and 10\% of all bank assets, according to Saunders and Walters (1994)). Similarly, Fenn et al. (1995) report that the largest institutions account for the vast majority of U.S. institutional holdings of private equity.

Structure of private equity finance. Fenn et al. (1995) estimate that only $30 \%$ of private equity in the U.S. is invested in venture capital, the rest being invested in larger and older firms. The dominant intermediary is a limited partnership fund, typically financed by large institutions (wealthy individuals, endowments, nonfinancial corporations, etc. only account for roughly a third of funding), in which the fund's general partner is the active monitor of investments. Often, new investments are channeled into a new fund involving the same general partner and limited investors. Within an existing fund, it is common (especially in venture capital -- see Sahlman) for limited partners to commit to provide funding at the outset rather than advance all the cash at once; this gives the limited partners the right to refuse additional funding, albeit at the expense of the funds they have already advanced. These features create severe liquidity needs as existing investments require additional funding or new opportunities become available. Thus, while liquidity needs are probably not as "immediate" as in the case of a bank, finance company, or mutual fund (all of which rely heavily on short-term financing), so that $\lambda$ is lower, these needs are significant and involve high opportunity costs $\beta$ when they do occur.

As documented by Sahlman (1990), venture capital finance typically takes the form of convertible preferred stock, with control exercised through a combination of board representation, covenants, and the use of staged financing. The preferred feature has generally been motivated as reducing the fund's risk if the firm performs poorly or only marginally well, and providing the manager (who holds common stock or options) with additional incentive to achieve good outcomes. This paper suggests yet another benefit: reducing the fund's downside risk mitigates lemons problems. Similarly, the staged financing feature gives the venture capitalist control without the necessity of controlling a majority of the voting shares -- and taking on more of the firm's risk -- from the outset. ${ }^{29}$ Fenn et al. (1995) suggest that convertible preferred is the most common form of investment in nonventure private equity finance as well, although the use of staged financing is less common.

Further research directions. Empirically, the cross-sectional predictions sketched above can be

\footnotetext{
${ }^{29}$ Nevertheless, as by Gompers (1993), the conversion feature is useful in order to reduce the manager's incentives for risk-shifting; also, preferred stock avoids some of the legal costs associated with transfer of control to debtolders, as well as potential "equitable subordination" in bankruptcy. Both issues are likely to loom large, given the high chance of failure for these firms.
} 
subjected to more rigorous tests. Additional tests might be found in relation to the structure of private equity funds. For example, Fenn et al. (1995) note that, unlike new ventures, many nonventure firms that take private equity finance have access to other sources of funds, including debt finance (both bank loans and privately-placed debt) and in some cases publicly-traded equity. Furthermore, while venture capital firms typically require high investment relative to liquidation value (although the latter includes the opportunity to sell a poorly-performing firm to a large corporation) and have high failure rates, nonventure situtations often have relatively more liquidation value and somewhat less skewed return distributions, so they are somewhat more likely to permit reduced monitoring. Thus, the model predicts a greater use of common stock, or preferred with lower par value and dividends, in the case of nonventure finance as compared with venture capital.

On a theoretical note, the link between the institution's funding structure and liquidity needs should be explicitly modeled. Although I have sketched some ways in which the level of liquidity needs should vary with funding structure, this structure is also driven by the need to control institutional moral hazard: as shown by Calomiris and Kahn (1990) and Flannery (1994), the use of demandable or otherwise short-term funding provides a liquidity threat that can help discipline the institution. To the extent liquidity crises are caused by such information-based "runs" rather than customer liquidity needs per se, there should be a negative correlation between liquidity needs and institutional asset quality (see also Chari and Jagannathan (1988)). Furthermore, an institution with largely long-term financing may have less discipline as well as fewer liquidity needs, which could actually weaken its monitoring incentives. Modeling these issues should yield richer results on optimal institutional structure. In addition, although I have mentioned the potential for institutional liquidity needs to damage valuable information, this remains to be modeled. 


\section{Appendix A: Results On The Equity Issuance Game}

Notation. The institution's private knowledge ("type") is written as (p,k), where $\mathrm{p}$ is her conditional belief about the firm's chance of success, and $\mathrm{k}$ equals 1 if the institution has liquidity needs and $\mathrm{n}$ if she does not. Let $\mathrm{b}(\mathrm{k})=\beta$ if $\mathrm{k}=1$ and 0 otherwise. If $(\mathrm{p}, \mathrm{k})$ issues $\phi$ shares at price $\mathrm{P}(\phi)$, its expected return is

$$
\mathrm{R}(\phi, \mathrm{p}, \mathrm{k}) \quad=\quad \phi \cdot(1+\mathrm{b}(\mathrm{k})) \cdot \mathrm{P}(\phi)+(1-\phi) \cdot \mathrm{V}(\mathrm{p}) .
$$

Lemma A.1. In any equilibrium of the equity-issuance game described in Section 3.B, for any two types $(\mathrm{p}, \mathrm{k}) \neq\left(\mathrm{p}^{\prime}, \mathrm{k}^{\prime}\right)$, if $\mathrm{V}(\mathrm{p}) /(1+\mathrm{b}(\mathrm{k}))<\mathrm{V}\left(\mathrm{p}^{\prime}\right) /\left(1+\mathrm{b}\left(\mathrm{k}^{\prime}\right)\right)$, then the types' choice of equity levels $\phi(\cdot)$ satisfy $\phi(\mathrm{p}, \mathrm{k}) \equiv \phi \geq \phi\left(\mathrm{p}^{\prime}, \mathrm{k}^{\prime}\right) \equiv \phi^{\prime}$.

Proof: suppose $\mathrm{V}(\mathrm{p}) /(1+\mathrm{b}(\mathrm{k}))<\mathrm{V}\left(\mathrm{p}^{\prime}\right) /\left(1+\mathrm{b}\left(\mathrm{k}^{\prime}\right)\right)$ and $\phi<\phi^{\prime}$. If this is an equilibrium, we must have $\mathrm{R}(\phi, \mathrm{p}, \mathrm{k}) \geq \mathrm{R}\left(\phi^{\prime}, \mathrm{p}, \mathrm{k}\right)$ and $\mathrm{R}\left(\phi^{\prime}, \mathrm{p}^{\prime}, \mathrm{k}^{\prime}\right) \geq \mathrm{R}\left(\phi, \mathrm{p}^{\prime}, \mathrm{k}^{\prime}\right)$. The first condition is equivalent to $\phi \cdot \mathrm{P}(\phi)-\phi^{\prime} \cdot \mathrm{P}\left(\phi^{\prime}\right) \geq$ $\left(\phi-\phi^{\prime}\right) \cdot \mathrm{V}(\mathrm{p}) /(1+\mathrm{b}(\mathrm{k}))$. The second condition is equivalent to $\phi^{\prime} \cdot \mathrm{P}\left(\phi^{\prime}\right)-\phi \cdot \mathrm{P}(\phi) \geq\left(\phi^{\prime}-\phi\right) \cdot \mathrm{V}\left(\mathrm{p}^{\prime}\right) /\left(1+\mathrm{b}\left(\mathrm{k}^{\prime}\right)\right)$ $>\left(\phi^{\prime}-\phi\right) \cdot \mathrm{V}(\mathrm{p}) /(1+\mathrm{b}(\mathrm{k}))$, where the second inequality follows from the initial assumptions. Multiplying both sides of the first condition by -1 quickly yields a contradiction.Q.E.D.

Lemma A.2. Take an equilibrium of the equity-issuance game described in Section 3.B, and examine a possible off-equilibrium equity issue of $\phi^{\prime \prime}$. (a) Then the D1 refinement concentrates beliefs about the deviator on either the type $(\mathrm{p}, \mathrm{k})$ with the highest $\mathrm{V}(\cdot) /(1+\mathrm{b}(\cdot))$ of all types with $\phi(\cdot)>\phi^{\prime \prime}$, or the type $\left(\mathrm{p}^{\prime}, \mathrm{k}^{\prime}\right)$ with the lowest $\mathrm{V}(\cdot) /(1+\mathrm{b}(\cdot))$ of all types with $\phi(\cdot)<\phi^{\prime \prime}$, or both. (I.e., beliefs concentrate on one or both of the types whose choices $\phi(\cdot)$ bracket $\phi^{\prime \prime}$ and whose values of $\mathrm{V}(\mathrm{p}) /(1+\mathrm{b}(\mathrm{k}))$ are closest together.) (b) Beliefs concentrate on $\left.(\mathrm{p}, \mathrm{k})\left(\mathrm{on} \mathrm{p}^{\prime}, \mathrm{k}^{\prime}\right)\right)$ iff

$$
\phi \cdot \mathrm{P}(\phi)-\left(\phi-\phi^{\prime \prime}\right) \cdot \mathrm{V}(\mathrm{p}) /(1+\mathrm{b}(\mathrm{k}))<(>) \phi^{\prime} \cdot \mathrm{P}\left(\phi^{\prime}\right)-\left(\phi^{\prime}-\phi^{\prime \prime}\right) \cdot \mathrm{V}\left(\mathrm{p}^{\prime}\right) /\left(1+\mathrm{b}\left(\mathrm{k}^{\prime}\right)\right)
$$

with equality between these expressions, any distribution over $(\mathrm{p}, \mathrm{k})$ and $\left(\mathrm{p}^{\prime}, \mathrm{k}^{\prime}\right)$ is acceptable under D1.

Proof: D1 puts no weight on types for whom the set of consistent beliefs (i.e., possible posteriors upon seeing $\left.\phi^{\prime \prime}\right)$ that support their deviation is strictly contained within the set of consistent beliefs that support deviation for another type. In this setting, beliefs matter only through the price $\left.\mathrm{P} \phi^{\prime \prime}\right)$ they imply, where $\mathrm{P}\left(\phi^{\prime \prime}\right)$ is the conditional expected value of the claim given the beliefs that follow an equity issue $\phi^{\prime \prime}$.

(a) Take $(\mathrm{p}, \mathrm{k})$ as defined in the lemma and any other $\left(\mathrm{p}, \mathrm{k}_{1}\right)$ with $\phi(\cdot)>\phi^{\prime \prime} . \mathrm{V}(\mathrm{p}) /(1+\mathrm{b}(\mathrm{k}))>$ $\mathrm{V}\left(\mathrm{p}_{1}\right) /\left(1+\mathrm{b}\left(\mathrm{k}_{1}\right)\right.$, so Lemma A.1 implies $\phi(\mathrm{p}, \mathrm{k}) \equiv \phi \leq \phi\left(\mathrm{p}_{1}, \mathrm{k}_{1}\right) \equiv \phi_{1}$. Then $(\mathrm{p}, \mathrm{k})$ deviates iff $\mathrm{R}\left(\phi^{\prime \prime}, \mathrm{p}, \mathrm{k}\right) \geq$ $\mathrm{R}(\phi, \mathrm{p}, \mathrm{k})$, which (with some manipulation) is equivalent to

$$
\mathrm{P}\left(\phi^{\prime \prime}\right) \geq \phi \cdot \mathrm{P}(\phi) / \phi^{\prime \prime}-\left[\left(\phi-\phi^{\prime \prime}\right) / \phi^{\prime \prime}\right] \cdot \mathrm{V}(\mathrm{p}) /(1+\mathrm{b}(\mathrm{k}))
$$

Similarly, $\left(\mathrm{p}_{1}, \mathrm{k}_{1}\right)$ deviates iff $\mathrm{R}\left(\phi^{\prime \prime}, \mathrm{p}_{1}, \mathrm{k}_{1}\right) \geq \mathrm{R}\left(\phi_{1}, \mathrm{p}_{1}, \mathrm{k}_{1}\right)$, and (by equilibrium) $\mathrm{R}\left(\phi_{1}, \mathrm{p}_{1}, \mathrm{k}_{1}\right) \geq \mathrm{R}\left(\phi, \mathrm{p}_{1}, \mathrm{k}_{1}\right)$; combining these two conditions and manipulating yields

$$
\mathrm{P}\left(\phi^{\prime \prime}\right) \geq \phi \cdot \mathrm{P}(\phi) / \phi^{\prime \prime}-\left[\left(\phi-\phi^{\prime \prime}\right) / \phi^{\prime \prime}\right] \cdot \mathrm{V}\left(\mathrm{p}_{1}\right) /\left(1+\mathrm{b}\left(\mathrm{k}_{1}\right)\right)
$$

Since $\phi>\phi^{\prime \prime}$ and $\mathrm{V}(\mathrm{p}) /(1+\mathrm{b}(\mathrm{k}))>\mathrm{V}\left(\mathrm{p}_{\mathrm{l}}\right) /\left(1+\mathrm{b}\left(\mathrm{k}_{1}\right)\right)$, it follows that, for any $\mathrm{P}(\phi)$ for which $\left(\mathrm{p}_{1}, \mathrm{k}_{1}\right)$ weakly prefers to deviate, $(\mathrm{p}, \mathrm{k})$ strictly prefers to deviate, so D1 implies that no weight is put on the possibility that the deviator is type $\left(\mathrm{p}_{1}, \mathrm{k}_{1}\right)$. 
Now take $\left(\mathrm{p}^{\prime}, \mathrm{k}^{\prime}\right)$ as defined in the lemma and any other $\left(\mathrm{p}_{1}, \mathrm{k}_{1}\right)$ with $\phi(\cdot)<\phi^{\prime \prime}$. Lemma A.1 implies $\phi\left(\mathrm{p}^{\prime}, \mathrm{k}^{\prime}\right) \equiv \phi^{\prime} \geq \phi\left(\mathrm{p}_{1}, \mathrm{k}_{1}\right) \equiv \phi_{1}$, and the same series of steps performed in (a) shows that for any $\mathrm{P}\left(\phi^{\prime \prime}\right)$ for which $\left(\mathrm{p}_{1}, \mathrm{k}_{1}\right)$ weakly prefers to deviate, $\left(\mathrm{p}^{\prime}, \mathrm{k}^{\prime}\right)$ strictly prefers to deviate, so D1 implies that no weight is put on the possibility that the deviator is type $\left(\mathrm{p}_{1}, \mathrm{k}_{1}\right)$.

(b) The set of prices for which $(\mathrm{p}, \mathrm{k})$ deviates is $\left\{\mathrm{P} \mid \mathrm{P} \geq \phi \cdot \mathrm{P}(\phi) / \phi^{\prime \prime}-\left[\left(\phi-\phi^{\prime \prime}\right) / \phi^{\prime \prime}\right] \cdot \mathrm{V}(\mathrm{p}) /(1+\mathrm{b}(\mathrm{k}))\right\}$; the set of prices for which $\left(\mathrm{p}^{\prime}, \mathrm{k}^{\prime}\right)$ deviates has similar form. The rest of the proof is immediate. Q.E.D.

Lemma A.3. Given equilibrium equity issuance levels $\phi(\mathrm{p}, \mathrm{k})$, the ex-ante expected return of the institution equals

$$
\alpha(1-q) \cdot V(0)+(1-\alpha) \cdot V(q)+\alpha q \cdot V(1)+\lambda \beta \sum_{p^{\prime}=0, q, 1}\left[\operatorname{Prob}\left\{p=p^{\prime}\right\} \phi\left(p^{\prime}, \ell\right) P\left(\phi\left(p^{\prime}, \ell\right)\right)\right]
$$

Proof: this return equals the expectation of $\mathrm{R}(\phi(\mathrm{p}, \mathrm{k}), \mathrm{p}, \mathrm{k})$ taken over all $(\mathrm{p}, \mathrm{k})$. Since $\mathrm{R}(\phi, \mathrm{p}, \mathrm{k})=$ $\phi P(\phi)(1+\beta)+(1-\phi) \mathrm{V}(\mathrm{p})$, and in equilibrium $\mathrm{P}(\phi)$ is the expected value of the institution's claim, given that she has issued $\phi$ equity, the expected value of $P(\phi(p, k))$ over all equilibrium types $(p, k)$ must equal $\mathrm{E}[\mathrm{V}(\mathrm{p})]$. Also, $\operatorname{Pr}\left\{\mathrm{p}=\mathrm{p}^{\prime}, \mathrm{k}=1\right\}=\lambda \cdot \operatorname{Pr}\left\{\mathrm{p}=\mathrm{p}^{\prime}\right\}$. The result follows immediately. Q.E.D.

Proposition A.4. Suppose that the value V(q) of an uninformed investor's claim equals the value $\mathrm{V}(0)$ of a bad investor.

(i) If $\mathrm{V}(0)<\mathrm{V}(1) /(1+\beta)$, good investors issue no equity, regardless of liquidity needs. Uninformed and bad investors issue the maximum amount of equity $(\phi=1)$ at price $V(0)$. (Henceforth, this will be referred to as the separating equilibrium.)

(ii) If $\mathrm{V}(0)>\mathrm{V}(1) /(1+\beta)$, good investors with liquidity needs pool with uninformed and bad investors, while good investors without liquidity needs issue no equity. The ex-ante optimal equilibrium has all investor types besides the good investor without liquidity needs pool and issue the maximum amount of equity; the pooling price is denoted $\mathrm{P}_{\mathrm{M}}(\alpha)$, and equals

$$
P_{M}(\alpha)=\frac{\alpha(1-q) V(0)+(1-\alpha) V(q)+\alpha q \lambda V(1)}{\alpha(1-q)+1-\alpha+\alpha q \lambda}
$$

Proof: (i) The types in descending order of $\mathrm{V}(\mathrm{p}) /(1+\mathrm{b}(\mathrm{k}))$ are $(1, \mathrm{n}),(1,1),(0, \mathrm{n}),(0, \mathrm{l})$; by Lemma $\mathrm{A} .1$, this is the weakly ascending order of equilibrium equity issuance. If $(1,1)$ pools with lower types $(p=$ 0 ) at some positive $\phi$, then she prefers to deviate to $\phi-\varepsilon$ for $\varepsilon$ sufficiently small: by Lemma A.2, beliefs concentrate on either $(1, n)$ or $(1,1)$, so $P(\phi-\varepsilon)=V(1)>P(\phi)$, and $(1,1)$ gets a strictly larger price on an amount of equity that is only marginally less.

However, if $(1,1)$ separates at $\phi>0,(0, n)$ prefers to imitate her rather than separate and receive $\mathrm{V}(0)$ for any shares she issues. Thus $\phi(1, \mathrm{l})=0$, which implies $\phi(1, \mathrm{n})=0$. $(0,1)$ strictly prefers to sell some equity at $\mathrm{V}(0)$ and receive the liquidity benefit $\mathrm{V}(0)(1+\beta)$ rather than sell no shares and simply receive $V(0)$, so she separates; clearly, she strictly prefers $\phi(0,1)=1$. $(0, n)$ is now indifferent between all levels of equity issuance; since her action does not affect the equilibrium actions 
and prices received by other types, assume she chooses $\phi=1$.

(ii) The order of types is $(1, n),(0, n),(1,1),(0,1)$. Since $V(0)>V(1) /(1+\beta),(1,1)$ strictly prefers to issue shares at price $\mathrm{V}(0)$ or above rather than issue no shares. $(1, \mathrm{n})$ clearly prefers issuing no shares to pooling. $(0, n)$ would rather pool with $(1,1)$ than separate. If $(1,1)$ tries to separate from $(0, \mathrm{n})$ by deviating to $\phi-\varepsilon, \mathrm{D} 1 \mathrm{implies}$ she is taken to be $(0, \mathrm{n})$, which is unprofitable. If $(0,1)$ pools with $(1,1)$ and $(0, n)$, or separates but is indifferent to pooling with them, deivations to $\phi+\varepsilon$ are viewed as coming from $(0,1)$; otherwise, for $\varepsilon$ small, they signal $(1,1)$, and pooling breaks down. Thus, in equilibrium, $(1,1)$ pools with $(0, n)$, and $(0,1)$ either pools or separates at 1 but is indifferent between that and pooling.

The maximum-pooling equilibrium satisfies D1, since deviations to lower positive equity levels are perceived as signaling $(0, \mathrm{n})$ and thus receive a price $\mathrm{V}(0)<\mathrm{R}(\alpha)$, which is unprofitable. This equilibrium ex-ante dominates other equilibria in which the same three types pool at some $\phi<1$ (by Lemma A.3, ex ante expected return is $\mathrm{E}[\mathrm{V}(\mathrm{p})]+\lambda \beta(1-\alpha q(1-\lambda)) \phi \cdot \mathrm{P}_{\mathrm{M}}(\alpha)$, versus $\mathrm{E}[\mathrm{V}(\mathrm{p})]+\lambda \beta(1-\alpha q(1-\lambda)) \mathrm{P}_{\mathrm{M}}(\alpha)$ for the maximum-pooling equilibrium.)

The maximum-pooling equilibrium also dominates equilibria in which $(0,1)$ separates all or part of the time: if $(0,1)$ separates, she might as well issue the maximum amount, 1 . Since she weakly prefers this to pooling with $(0, \mathrm{n})$ and $(1,1)$ at $\phi<1$, it must be that $(1+\beta) \mathrm{V}(0) \geq(1+\beta) \phi \mathrm{P}(\phi)+(1$ $\phi) \mathrm{V}(0)>(1+\beta) \phi \mathrm{P}(\phi)$, so $\mathrm{V}(0)>\phi \mathrm{P}(\phi)$. By lemma A.3, ex ante expected returns in this equilibrium are $\mathrm{E}[\mathrm{V}(\mathrm{p})]+\lambda \beta[(1-\alpha q) \mathrm{V}(0)+(\alpha q \lambda) \phi \mathrm{P}(\phi)]$, as compared with $\mathrm{E}[\mathrm{V}(\mathrm{p})]+\lambda \beta \cdot \mathrm{P}(\alpha)$ in the maximumpooling equilibrium; the maximum-pooling equilibrium is better, since $\mathrm{R}_{\mathrm{M}}(\alpha)>\mathrm{V}(0)>\phi \mathrm{P}(\phi)$. Q.E.D.

Proposition A.5. Suppose that the value $V(q)$ of an uninformed investor's claim exceeds the value $\mathrm{V}(0)$ of a bad investor, so that $\mathrm{V}(\mathrm{q})=\mathrm{q} \mathrm{V}(1)>\mathrm{V}(0)$.

(i) If $\mathrm{V}(\mathrm{q})<\mathrm{V}(1) /(1+\beta)$, good investors issue no equity, regardless of liquidity needs, as do uninformed investors without liquidity needs.

(a) If $\mathrm{V}(0)<\mathrm{V}(\mathrm{q}) /(1+\beta)$, uninformed investors issue no equity, regardless of liquidity needs, and bad investors issue the maximum amount of equity, regardless of liquidity needs.

(b) If $\mathrm{V}(0)>\mathrm{V}(\mathrm{q}) /(1+\beta)$, then uninformed investors with liquidity needs pool with bad investors. In the ex-ante optimal equilibrium, uninformed investors with liquidity needs and bad investors pool and issue the maximum amount of equity.

(ii) Suppose $\mathrm{V}(\mathrm{q})>\mathrm{V}(1) /(1+\beta)$. Good investors without liquidity needs issue no equity.

(a) If $\mathrm{V}(\mathrm{q}) \leq \mathrm{P}_{\mathrm{M}}(1)$, the ex-ante optimal equilibrium is the maximum-pooling equilibrium from Proposition A.4(ii).

(b) Suppose $V(q)>P_{M}(1)$. (1) If $V(q) /(1+\beta)>V(0)$, the separating equilibrium from (i.a) is feasible. (2) If $\mathrm{V}(\mathrm{q}) /(1+\beta)<\mathrm{V}(0)<\mathrm{V}(1) /(1+\beta)$, then in one equilibrium, uninformed investors without liquidity needs and good investors with liquidity needs issue a unique amount of equity $\phi(\alpha) \in$ $(0,1)$ defined in the appendix, while all remaining types issue the maximum amount of equity. As the probability $\alpha$ of monitoring approaches one, $\phi(\alpha)$ tends to zero. (3) If $\mathrm{V}(0)>\mathrm{V}(1) /(1+\beta)$, then in the ex-ante optimal equilibrium, uninformed investors without liquidity needs issue no equity, while all remaining types pool at the maximum amount of equity.

Proof: (i) The proof that good types separate by issuing no equity follows the same logic as in Proposition A.4(i). Given this result, parts (a) and (b) follow the same logic as Proposition A.4(i) and (ii) respectively, with uninformed types taking the role of the good types in the previous proposition. (In particular, in part (b), uninformed investors with liquidity needs pool with bad investors without liquidity needs; among such equilibria, the ex-ante optimal one involves pooing at $\phi=1$.

(ii) Since type $(1, n)$ strictly prefers issuing no equity rather than pooling with lower types, she 
weakly prefers to issue no equity; without loss of generality, assume she issues no equity.

(a) If $\mathrm{V}(\mathrm{q}) \leq \mathrm{P}_{\mathrm{M}}(1)$, then uninformed investors prefer the maximum-pooling equilibrium, where they issue the maximum amount at price $\mathrm{P}_{\mathrm{M}}(\alpha)$, to separating at some lower $\phi$ and receiving $\mathrm{V}(\mathrm{q})$; this follows because $P_{M}(\alpha)$ is a weighted average of $P_{M}(1)$ and $V(q)$. If any of the types that are supposed to pool deviate from this equilibrium, they are perceived as type $(q, n)((q, n)$ has the least preference for issuing equity, except for $(1, n)$, who separates), so they receive $V(q)$ on $\phi<1$ shares. Since this is strictly dominated by receiving $\mathrm{P}_{\mathrm{M}}(\alpha)$ on 1 share, the maximum-pooling equilibrium satisfies $\mathrm{D} 1$. The proof that this dominates other equilibria follows the same logic as in Proposition A.4(ii).

(b) Once again, $(1, n)$ separates at zero; now, since she has the next highest $V(p) /(1+b(k))$, $(\mathrm{q}, \mathrm{n})$ prefers to separate at a lower level rather than pool with everyone else.

In case (1), type $(\mathrm{q}, 1)$ prefers to deviate down slightly rather than pool with the bad types $(0, \mathrm{n})$ and $(0,1)$ alone. She might be willing to pool with $(1,1)$ and the bad types. However, in this case, the pooling price would be a weighted average of $P_{M}(1)$ and $V(q)$, and $(1,1)$ prefers to deviate down slightly and be taken for either herself or $(q, n)$, receiving $V(q)$ or $V(1)$. Rather than separate, $(0, n)$ will imitate the higher types if they pool at any positive level. The equilibrium from (i.a) is feasible, since D1 implies that any deviation is taken to signal type $(0, n)$, which is unprofitable.

In case $(2)$, type $(\mathrm{q}, 1)$ is now willing to pool with the bad types only rather than separate; suppose (for simplicity) all three types issue the maximum amount of equity. As in case (1), types $(1,1)$ and $(\mathrm{q}, \mathrm{n})$ still won't pool with the first three types, but they issue a small enough amount of equity $\phi$, type $(0, n)$ won't imitate them. If $(0, n)$ strictly prefers to issue 1 rather than $\phi,(1,1)$ can signal her type by a small positive deviation (applying Lemma $A .2(b)$ ), so $(0, n)$ is indifferent between 1 and $\phi$; i.e., $\mathrm{P}(1)=\phi \mathrm{P}(\phi)+(1-\phi) \mathrm{V}(0)$, so $\phi=[\mathrm{P}(1)-\mathrm{V}(0)] /[\mathrm{P}(\phi)-\mathrm{V}(0)]$. Taking conditional expectations,

$$
P(1)=\frac{\alpha(1-q) \cdot V(0)+(1-\alpha) \lambda \cdot V(q)}{\alpha(1-\lambda)+(1-\alpha) \lambda}, \quad P(\phi)=\frac{(1-\alpha)(1-\lambda) \cdot V(q)+\alpha \lambda q \cdot V(1)}{(1-\alpha)(1-\lambda)+\alpha \lambda q}
$$

Thus, as $\alpha \rightarrow 1, \mathrm{P}(1) \rightarrow \mathrm{V}(0)$, and $\mathrm{P}(\phi) \rightarrow \mathrm{V}(1)$, so $\phi \rightarrow 0$.

In case (3), all types with liquidity needs $(k=1)$ prefer pooling at 1 to separating at 0 . If $(0, n)$ pools with them at $1,(q, n)$ clearly prefers separation (and price $V(q)$ ) to pooling and getting a weighted average of $\mathrm{V}(\mathrm{q})$ and $\mathrm{P}_{\mathrm{M}}(1)$. If $(\mathrm{q}, \mathrm{n})$ chooses to high a level $\phi,(0, \mathrm{n})$ will deviate from 1 to $\phi$; otherwise, $(\mathrm{q}, \mathrm{n})$ is indifferent, so assume she chooses 0 . Any deviation from 1 then signals type $(0, \mathrm{n})$, and is thus unprofitable. This dominates any pooling equilibria with lower levels of equity issuance through the same line of argument used in the proof of Proposition A.4(ii). Q.E.D.

Proposition A.6. (i) Suppose that one of the following conditions holds:

(a) $\mathrm{V}(\mathrm{q})=\mathrm{V}(0)<\mathrm{V}(1) /(1+\beta)$ (Proposition $A .4(i))$,

(b) $\mathrm{V}(\mathrm{q})>\mathrm{V}(0)$ and $\mathrm{V}(\mathrm{q})<\mathrm{V}(1) /(1+\beta)$ (Proposition $A .5(i))$, or

(c) $\mathrm{V}(\mathrm{q})>\mathrm{P}_{\mathrm{M}}(1)$ and $\mathrm{V}(\mathrm{q})>\mathrm{V}(1) /(1+\beta)$ (Proposition A.5(ii.b))

Then if the individual rationality condition (IR) holds, the incentive compatibility condition (IC) must hold strictly, and the institution monitors with certainty in equilibrium.

(ii) Suppose that $\mathrm{PM}_{\mathrm{M}}(1)<\mathrm{I}$, and either of the following conditions holds:

(a) $\mathrm{V}(\mathrm{q})=\mathrm{V}(0)>\mathrm{V}(1) /(1+\beta)$ (Proposition A.4(ii)), or

(b) $\mathrm{V}(\mathrm{q})>\mathrm{V}(0), \mathrm{V}(\mathrm{q})>\mathrm{V}(1) /(1+\beta)$, and $\mathrm{V}(\mathrm{q}) \leq \mathrm{P}_{\mathrm{M}}(1)$ (Proposition A.5(ii.a)).

Then if the individual rationality condition (IR) holds, the incentive compatibility condition (IC) must hold strictly, and the institution monitors with certainty in equilibrium. 
Proof: (i) As noted in the text, if $\mathrm{N}(v, \mathrm{D}) \leq \mathrm{V}(\mathrm{q})(1+\lambda \beta)$, then it follows that, whenever (IR) is satisfied, (IC) holds strictly, and so the institution chooses monitoring with certainty. In case (a), $\mathrm{N}(v, \mathrm{D})=(1+\lambda \beta) \cdot \mathrm{V}(0)=(1+\lambda \beta) \cdot \mathrm{V}(\mathrm{q})$. In case $(\mathrm{b})$, the uninformed investor issues no equity when she has no liquidity needs. When she has liquidity needs, she either issues no equity or issues the maximum amount, pooling with the bad types; in the second case, the issue price $\mathrm{P}(1)$ is a weighted average of $\mathrm{V}(0)$ and $\mathrm{V}(\mathrm{q})$, so that $\mathrm{P}<\mathrm{V}(\mathrm{q})$. Thus, $\mathrm{N}(\mathrm{v}, \mathrm{D})$ is either $\mathrm{V}(\mathrm{q})$ or $(1-\lambda) \cdot \mathrm{V}(\mathrm{q})+$ $\lambda(1+\beta) \cdot \mathrm{P}(1)$; either way, $\mathrm{N}(\mathrm{v}, \mathrm{D})<(1+\lambda \beta) \mathrm{V}(\mathrm{q})$. In case $(\mathrm{c}), \mathrm{V}(\mathrm{q})>\mathrm{PM}(1), \mathrm{V}(1) /(1+\beta)$. There are three subcases:

(1) $\mathrm{V}(\mathrm{q}) /(1+\beta)>\mathrm{V}(0)$. This is equivalent to case (b) above.

(2) $\mathrm{V}(1) /(1+\beta)>\mathrm{V}(0)>\mathrm{V}(\mathrm{q}) /(1+\beta)$. In this case,

$$
\mathrm{N}(v, \mathrm{D})=(1-\lambda)[\phi \cdot \mathrm{P}(\phi)+(1-\phi) \cdot \mathrm{V}(\mathrm{q})]+\lambda(1+\beta) \mathrm{P}(1),
$$

where $\phi, \mathrm{P}(\phi)$, and $\mathrm{P}(1)$ are defined in the proof of Proposition A.5(ii.b.2). Define $\Delta=$ $\mathrm{N}(\nu, \mathrm{D})-(1+\lambda \beta) \cdot \mathrm{V}(\mathrm{q})$; I need to show $\Delta \leq 0$. Noting that $(1+\lambda \beta)=1-\lambda+\lambda(1+\beta)$, it follows that

Substituting in the definitions of $\mathrm{P}(\phi)$ and $\mathrm{P}(1)$ followed by tedious algebra leads to

Thus, showing that $\Delta \leq 0$ is equivalent to showing that the second bracketed term is nonpositive. Combining terms and factoring out the denominator, the sign of this term is the same as that of

Since $\mathrm{V}(\mathrm{q})=\mathrm{q} \cdot \mathrm{V}(1)>\mathrm{P}_{\mathrm{M}}(1), \mathrm{V}(0)<\mathrm{q}(1-\lambda) \mathrm{V}(1)$, and so $\mathrm{V}(0)-\mathrm{V}(\mathrm{q})<-\lambda \mathrm{q} \cdot \mathrm{V}(1)=-\lambda \mathrm{V}(\mathrm{q})$. THus the expression above is less than 
(3) $\mathrm{V}(0)>\mathrm{V}(1) /(1+\beta)$. The uninformed investor issues no equity when she has no liquidity needs, getting $\mathrm{V}(\mathrm{q})$; when she has liquidity needs, she issues the maximum amount of equity, pooling with types $(1,1),(0, n)$, and $(0,1)$; the price she receives is a weighted average of $V(q)$ and $R(1)$. Since $\mathrm{V}(\mathrm{q})>\mathrm{P}_{\mathrm{M}}(1)$, it follows that $\mathrm{N}(v, \mathrm{D})<(1-\lambda) \cdot \mathrm{V}(\mathrm{q})+\lambda(1+\beta) \cdot \mathrm{V}(\mathrm{q})=(1+\lambda \beta) \cdot \mathrm{V}(\mathrm{q})$.

(ii) In both (a) and (b), the maximum-pooling equilibrium occurs; thus $\mathrm{N}(\mathrm{N}, \mathrm{D})=$ $(1+\lambda \beta) \mathrm{P}_{M}(\alpha)$. Since $\mathrm{V}(\mathrm{q}) \leq \mathrm{P}_{\mathrm{M}}(1), \mathrm{PM}_{\mathrm{M}}(\alpha) \leq \mathrm{P}_{\mathrm{M}}(1)<\mathrm{I}$; thus, whenever (IR) holds, $\mathrm{M}(v, \mathrm{D})>\mathrm{N}(v, \mathrm{D})$, so (IC) holds strictly and the institution monitors with certainty.Q.E.D. 
Appendix B: Proofs of Propositions in the Text

Proof of Proposition 2. (i) Case (a) is an immediate corollary of Proposition A.6(i.a,b). Case (b) corresponds to subcases (1) and (2) from Proposition A.6(i.c). Subcase (1) is clearly the separating equilibrium described, with monitoring $\alpha=1$; when $\alpha=1$, the equilibrium in subcase (2) corresponds to types $(1, \mathrm{n}),(1,1)$, and $(\mathrm{q}, \mathrm{n})$ issuing no equity, and the other types issuing the maximum amount 1 (see the proof of Proposition A.5(ii.b(2))), which again is equivalent to the separating equilibrium described.

(ii) Case (a) corresponds to subcase (3) from Proposition A.6(i.c); since $\alpha=1$ here, it is easy to see that this corresponds to the maximum-pooling equilibrium with $\alpha=1$. Case (b) corresponds to Proposition A.6(ii),. In both cases, it is easy to show that M( $(, D)$ has the form stated in the text. (IC) is $\mathrm{M}(\cdot) \geq \mathrm{N}(\cdot)$; since $\mathrm{N}(\nu, \mathrm{D})=(1+\lambda \beta) \cdot \mathrm{PM}_{\mathrm{M}}(\alpha)$, the condition in the text easily follows. Q.E.D.

Proof of Proposition 3. (i) This follows easily from the definitions $A(p), V(p)$, and $M(v, D)$. (Note that $\mathrm{q} \cdot \mathrm{V}(1)+(1-\mathrm{q}) \mathrm{V}(0)-\mathrm{M}(\cdot) /(1+\lambda \beta)=\mathrm{q} \cdot \mathrm{V}(1)-\mathrm{q} \cdot \mathrm{V}(1) /(1+\lambda \beta)-\mathrm{m}$.

(ii) When $\alpha=1$, the institution's initial investment less her expected payments equals $\mathrm{q}(1-\lambda)\left[\mathrm{V}(1)-\mathrm{P}_{\mathrm{M}}(1)\right] /(1+\lambda \beta)+\mathrm{P}_{\mathrm{M}}(1)-\mathrm{m}-[\mathrm{q} \cdot \mathrm{V}(1)+(1-\mathrm{q}) \mathrm{V}(0)] ;$ since $\mathrm{PM}_{\mathrm{M}}(1)-\{\mathrm{q} \cdot \mathrm{V}(1)+(1-\mathrm{q}) \mathrm{V}(0)\}$ equals

$\mathrm{P}_{M}(1)-\left\{\mathrm{q}(1-\lambda) \cdot \mathrm{V}(1)+[1-\mathrm{q}(1-\lambda)] \cdot \mathrm{P}_{\mathrm{M}}(1)\right\}=-\mathrm{q}(1-\lambda)\left[\mathrm{V}(1)-\mathrm{P}_{\mathrm{M}}(1)\right]$, the expression in the text follows easily.

When $\alpha<1$, (IC) holds as an equality, so $\mathrm{M}(\cdot) /(1+\lambda \beta)=\mathrm{N}(\cdot) /(1+\lambda \beta)=\mathrm{P}_{\mathrm{M}}(\alpha)$. Again, the institution's initial investment less her expected payments equals

$$
\mathrm{P}_{\mathrm{M}}(\alpha)-\{\alpha \mathrm{q} \cdot \mathrm{V}(1)+\alpha(1-\mathrm{q}) \cdot \mathrm{V}(0)+(1-\alpha) \cdot \mathrm{V}(\mathrm{q})\}=\mathrm{P}_{\mathrm{M}}(\alpha)-\left\{\alpha \mathrm{q}(1-\lambda) \cdot \mathrm{V}(1)+(1-\alpha \mathrm{q}(1-\lambda)) \cdot \mathrm{P}_{\mathrm{M}}(\alpha),\right.
$$

which in turn equals $-\alpha q(1-\lambda)\left[\mathrm{V}(1)-\mathrm{P}_{\mathrm{M}}(\alpha)\right]$. Since (IC) holds with equality, this equals $\alpha \mathrm{m}(1+\lambda \beta)$. The expression for the manager's objective function followseasily.Q.E.D.

Proof of Lemma 4. (i) The expressions for $V_{S}$ and $V_{P}$ follow by taking the individual rationality constraints for the relevant equilibria as equalities, solving for $\mathrm{V}(1)$, and setting $\mathrm{V}(0)$ equal to $\mathrm{L}$. (In the case of $V_{P}$, recall that $P_{M}(1)$ now equals $\left[(1-q) L+q \lambda V_{P}\right] /[1-q(1-\lambda)]$.) $V_{S}>V_{P}$ follows because $1+[\lambda \beta /(1-\mathrm{q}(1-\lambda))]>1+\lambda \beta$, while $\left[1+\lambda^{2} \beta /(1-\mathrm{q}(1-\lambda))\right]^{-1}<1$.

(ii) Comparative statics for Vs with regard to I, M, L, $\beta$, and $\lambda$ are straightforward, as are the comparative statics for $\mathrm{V}_{\mathrm{P}}$ with regard to $\mathrm{I}, \mathrm{m}$, and $\mathrm{L}$. Also, $\partial \mathrm{V}_{\mathrm{s}} / \partial \mathrm{q}=-[\mathrm{I}-\mathrm{m}-\mathrm{L}] / \mathrm{q}^{2}<0$, since $\mathrm{I}>\mathrm{L}$.

For the other results, note that $V_{P}$ solves $q(1-\lambda) V_{P}+[1-q(1-\lambda)+\lambda \beta] P_{M}(1)-(m+I)(1+\lambda \beta)=$ 0 . Denote the LHS of this equation by $F$. By the Implicit Function Theorem, $\partial \mathrm{V}_{\mathrm{P}} / \partial \mathrm{x}=$ $(\partial F / \partial x) /\left(\partial F / \partial V_{P}\right)$. Since $d P_{M}(1) / d V_{P}=q \lambda /[1-q(1-\lambda)], \partial F / \partial V_{P}=q(1-\lambda)+[-q(1-\lambda)+1+\lambda \beta] \cdot q \lambda /[1-q(1-$ $\lambda)]>0$. Thus, the sign of $\partial \mathrm{V}_{\mathrm{P}} / \partial \mathrm{x}$ is the opposite of the sign of $\partial \mathrm{F} / \partial \mathrm{x}$.

$\mathrm{V}_{\mathrm{P}} / \quad: \partial \mathrm{F} / \partial \beta=\lambda\left(\mathrm{P}_{\mathrm{M}}(1)-\mathrm{I}-\mathrm{m}\right)=-\lambda \mathrm{q}(1-\lambda)\left(\mathrm{V}_{\mathrm{P}}-\mathrm{P}_{\mathrm{M}}(1)\right) /(1+\lambda \beta)<0$, where the second equality follows from $\mathrm{F}=0$. Thus $\partial \mathrm{V}_{\mathrm{P}} / \partial \beta>0$.

$\mathrm{V}_{\mathrm{P}} / \mathrm{q}: \partial \mathrm{F} / \partial \mathrm{q}=(1-\lambda)\left[\mathrm{V}_{\mathrm{P}}-\mathrm{P}_{\mathrm{M}}(1)\right]+[1-\mathrm{q}(1-\lambda)+\lambda \beta]\left(\partial \mathrm{P}_{\mathrm{M}}(1) / \partial \mathrm{q}\right)>0\left(\partial \mathrm{P}_{\mathrm{M}}(1) / \partial \mathrm{q}>0\right.$, since an increase in $\mathrm{q}$ increases the weight on $\mathrm{V}_{\mathrm{P}}$ and reduces that on $\left.\mathrm{V}(0)=\mathrm{L}\right)$. Thus $\partial \mathrm{V}_{\mathrm{P}} / \partial \mathrm{q}<0$. Q.E.D.

Proof of Proposition 5: (i) If $V_{P}>X$, then $V_{s}>X$, so it is impossible to meet (IR) under either the maximum-pooling equilibrium with certain monitoring or the separating equilibrium. Maximum pooling with $\alpha<1$ at $\mathrm{V}(1)=\mathrm{VP}_{\mathrm{P}}$ and $\mathrm{V}(0)=\mathrm{L}$ reduces the pooling price $\mathrm{Pr}_{\mathrm{r}}(\alpha)$ and thus lowers $\mathrm{M}(\cdot)$, all else equal. Thus, to meet (IR), since $\mathrm{V}(0)$ cannot increase, $\mathrm{V}(1)$ must increase, which is not feasible.

(ii) By Proposition 2(i), if either (a) or (b) holds, then $\mathrm{V}(1)=\mathrm{V}_{\mathrm{p}}$ and $\mathrm{V}(0)=\mathrm{L}$ leads to a 
separating equilibrium. Increasing $\mathrm{V}(1)$ further (and possibly decreasing $\mathrm{V}(0)$ only makes one of these conditions more likely, so only a separating equilibrium is possible. If $\mathrm{V} s>\mathrm{X}$, even this is infeasible; otherwise, it is feasible. Since $\alpha=1$ in any separating equilibrium, the only concern for the manager is to minimize liquidity costs. By Proposition 3(i), this involves choosing $V(1)$ as small as possible, subject to (IR), so $\mathrm{V}(1)=\mathrm{Vs}, \mathrm{V}(0)=\mathrm{L}$ is the optimal choice. Generically, $\mathrm{D}<\mathrm{L}$ cannot achieve this, since $\mathrm{V}(0)=\mathrm{L}$ then requires that $\mathrm{V}=1$, which implies $\mathrm{V}(1)=\mathrm{X}>\mathrm{Vs}$.

Increases in $V_{\mathrm{P}} / \mathrm{L}$ and $\mathrm{V}_{\mathrm{P}} /(1+\beta)$ make (a) or (b) more likely to hold. Lemma 4 immediately shows that this is more likely as I or $\mathrm{m}$ increases, or $\mathrm{q}$ or $\mathrm{L}$ decreases.

$$
\mathrm{d}\left(\mathrm{V}_{\mathrm{P}} /(1+\beta)\right) / \mathrm{d} \beta=(1+\beta)^{-2} \cdot\left[(1+\beta)\left(\mathrm{d} \mathrm{V}_{\mathrm{P}} / \mathrm{d} \beta\right)-\mathrm{V}_{\mathrm{P}}\right] \text {. From the proof of Lemma } 4 \text {, }
$$

$$
\frac{d V_{p}}{d \beta}=\frac{\frac{\lambda q(1-\lambda)\left(V_{p}-P_{M}(1)\right)}{q+\frac{q \lambda^{2} \beta}{1-q(1-\lambda)}}}{q+\lambda \beta}=\frac{\lambda(1-q)(1-\lambda)\left(V_{p}-L\right)}{(1+\lambda \beta)\left(1-q(1-\lambda)+\lambda^{2} \beta\right)}<\frac{\lambda\left(V_{p}-L\right)}{1+\lambda \beta} \text {, }
$$

Since $\lambda(1+\beta)<1+\lambda \beta$, it follows that $d\left(V_{P} /(1+\beta)\right) / d \beta<(1+\beta)^{-2} \cdot\left[V_{P}-L-V_{P}\right]<0$.

(iii) Now, maximum pooling is possible with $\mathrm{V}(1)=\mathrm{V}_{\mathrm{P}}, \mathrm{V}(0)=\mathrm{L}$. Condition (13) in the text follows by substituting these values into (IC) for $\alpha=1$ and performing tedious algebra. An easier way to see this is to note that, for $\alpha=1$, (IC) is $m \leq q(1-\lambda)(1-q)[V(1)-V(0)] /[(1-q(1-\lambda))(1+\lambda \beta)]$. Thus, if (IR) holds exactly (as it does for these values and $\alpha=1$ ), and (IC) holds exactly at $\alpha=1$, then (IR) becomes $I=P_{M}(1)$, so that $I-V(0)=q \lambda[V(1)-V(0)] /[1-q(1-\lambda)]$, and so the RHS of (IC) is equivalent to $(1-\lambda)(1-q)[I-V(0)] /[\lambda(1+\lambda \beta)]$. Finally, substitute $L$ for $V(0)$.

The manager strictly prefers pooling to separating. At $\mathrm{V}(1)=\mathrm{V}_{\mathrm{P}}, \mathrm{V}(0)=\mathrm{L}$, equilibrium only meets (IR) if $\alpha=1$; any other equilibrium must have higher $V(1)$ and possibly lower $V(0)$, which makes (IC) hold strictly, so $\alpha<1$ is impossible. By Proposition 3(ii), the manager minimizes liquidity costs, which is equivalent to making $\mathrm{V}(1)-\mathrm{V}(0)$ as small as possible, subject to (IR); thus, $\mathrm{V}_{\mathrm{p}}$ and $\mathrm{L}$ are optimal. Again, this generically requires $\mathrm{D} \geq \mathrm{L}$.

Comparative statics on condition (13) immediately yield the remaining results. Q.E.D.

Proof of Proposition 6. If reduced monitoring occurs, the manager's objective function is given by (10) in Proposition 3. When $q X \geq V(0), A(q, v, D)=q X+C$, and the derivative of the objective function with respect to $\alpha$ is $(1-q)(L-C)-(1+\lambda \beta) m$. Since $L<C$ by assumption, this is negative. $V(0) \leq L$, so part (i) of the proposition follows immediately.

In part (ii), so long as $\mathrm{V}(0) \leq \mathrm{qX}$ is feasible and supports pooling, the same result holds. Otherwise, $\mathrm{V}(0)>\mathrm{qX}$ implies $\mathrm{A}(\mathrm{q}, \mathrm{v}, \mathrm{D})=\mathrm{L}$, and the derivative of the objective function with respect to $\alpha$ is $(1-q) L+q(X+C)-(1+\lambda \beta) m$. Either this is positive or certain monitoring isn't feasible (certain monitoring produces cash flows of $(1-q) L+q X$ and costs at least $(1+\lambda \beta) \mathrm{m}$ in monitoring and liquidity costs). However, if certain monitoring is not feasible, neither is reduced monitoring: total cash flows net of investment, monitoring, and liquidity costs would be $\alpha[(1-q) L+q X]+(1-\alpha) L-I-\alpha(1 \lambda \beta) m$, and this would be negative, since $L<I$. Thus, the derivative is positive, and the manager prefers as much monitoring as possible. Q.E.D. 


\section{References}

Akerlof, George (1970), "The Market for Lemons: Qualitative Uncertainty and the Market Mechanism." Quarterly Journal of Economics 84, 488-500.

Allen, Franklin, and Andrew Winton (1995), "Corporate Financial Structure, Incentives, and Optimal Contracting." In Handbooks in Operations Research and Management Science, Volume 9: Finance, eds. R. A. Jarrow, V. Maksimovic, and W. T. Ziemba, North Holland, New York.

Banks, Jeffrey, and Joel Sobel (1987), "Equilibrium Selection in Signaling Games. "Econometrica 55, 647-661.

Berlin, Mitchell, Kose John, and Anthony Saunders (1994), "Bank Equity Stakes in Borrowing Firms and Financial Distress." Finance Department Working Paper FD-94-17, Stern School, NYU.

Bhattacharya, Sudipto, and Anjan Thakor (1993), "Contemporary Banking Theory." Journal of Financial Intermediation 3, 2-50.

Board of Governors of the Federal Reserve System, Flow of Funds Accounts, various years.

Boyd, John, and Edward Prescott (1986), "Financial Intermediary Coalitions." Journal of Economic Theory 38, 211-232.

Cabral dos Santos, João (1995), "Bank Capital and Equity Investment Regulation." Working paper, Federal Reserve Bank of Cleveland.

Calomiris, Charles, and Charles Kahn (1991), "The Role of Demandable Debt in Structuring Optimal Banking Arrangements." American Economic Review 81, 497-513.

Carey, Mark, Mitchell Post, and Steven Sharpe (1996), "Does Lending by Banks and Finance Companies Differ?" Working paper, Board of Governors of the Federal Reserve System.

Carey, Mark, Stephen Prowse, John Rea, and Gregory Udell (1993), "The Economics of the Private Placement Market." Staff Study 166, Board of Governors of the Federal Reserve System.

Chari, V.V., and Ravi Jagannathan (1988), "Banking Panics, Information, and Rational Expectations Equilibrium." Journal of Finance 43, 749-761.

Cho, In-Koo, and David Kreps (1987), "Signaling Games and Stable Equilibria. "Quarterly Journal of Economics 102, 179-221.

DeMarzo, Peter, and Darrell Duffie (1995), "A Liquidity-Based Model of Security Design." Working paper, Stanford University.

Deutsche Bundesbank (1992). Monthly Report of the Deutsche Bundesbank, (July).

Diamond, Douglas (1984), "Financial Intermediation and Delegated Monitoring. "Review of Economic Studies 51, 393-414.

Diamond, Douglas (1993a), "Seniority and Maturity of Debt Contracts." Journal of Financial Economics 33, 341-368. 
Diamond, Douglas (1993b), "Bank Loan Maturity and Priority When Borrowers Can Refinance." In Capital Markets and Financial Intermediation, eds. Colin Mayer and Xavier Vives, Cambridge University Press, Cambridge, UK.

Edwards, Jeremy, and Klaus Fischer (1994). Banks, Finance, and Investment in Germany, Cambridge University Press, Cambridge, UK.

Fenn, George, Nellie Liang, and Stephen Prowse (1995), "The Economics of the Private Equity Market." Staff Study 168, Board of Governors of the Federal Reserve System.

Flannery, Mark (1994), "Debt Maturity and the Deaweight Cost of Leverage: Optimally Financing Banking Firms." American Economic Review 84, 320-331.

Gale, Douglas, and Martin Hellwig (1985), "Incentive Compatible Debt Contracts: The One Period Problem." Review of Economic Studies 52, 647-663.

Gale, Douglas, and Martin Hellwig (1989), "Repudiation and Renegotiation: The Case of Sovereign Debt." International Economic Review 30, 3-31.

Goergen, Marc (1995), "The Evolution of Ownership and Control in German IPOs." Working paper, Keble College and School of Management Studies, Oxford University.

Gompers, Paul (1993), "Incentives, Screening, and Venture Capital: A Role for Convertible Debt." Working paper, University of Chicago.

Gorton, Gary, and Frank Schmid (1996), "Universal Banking and the Performance of German Firms." Working paper, University of Pennsylvania.

Greenbaum, Stuart, and Anjan Thakor (1987), "Bank Funding Modes: Securitization versus Deposits." Journal of Banking and Finance 11, 379-401.

Harris, Milton, and Artur Raviv (1991), "The Theory of Capital Structure." Journal of Finance 46, 297-355.

Hirshleifer, Jack (1971), "The Private and Social Value of Information and the Reward to Inventive Activity." American Economic Review 61, 561-574.

James, Christopher (1995), "When Do Banks Take Equity in Debt Restructurings?" Review of Financial Studies 8, 1209-1234.

Kahn, Charles, and Andrew Winton (1996), "Ownership Structure, Speculation, and Shareholder Intervention." Finance Department Working Paper No. 220, Northwestern University.

Krasa, Stefan, and Anne Villamil (1992), "Monitoring the Monitor: An Incentive Structure for a Financial Intermediary." Journal of Economic Theory 57, 197-221.

Krasa, Stefan, and Anne Villamil (1994), "Optimal Contracts with Costly State Verification: The Multilateral Case." Economic Theory 4, 167-187.

Lucas, Deborah, and Robert McDonald (1987), "Bank Portfolio Choice With Private Information About Loan Quality." Journal of Banking and Finance 11, 473-497.

Lucas, Deborah, and Robert McDonald (1992), "Bank Financing and Investment Decisions with 
Asymmetric Information About Loan Quality." RAND Journal of Economics 23, 86-105.

Mookherjee, Dilip, and Ivan Png (1989), "Optimal Auditing, Insurance, and Redistribution." Quarterly Journal of Economics 104, 399-415.

Myers, Stewart, and Nicolas Majluf (1984), "Corporate Investment and Financing Decisions When Firms Have Information That Investors Do Not Have." Journal of Financial Economics 13, 187-222.

O'Hara, Maureen (1993), "Real Bills Revisited: Market Value Accounting and Loan Maturity." Journal of Financial Intermediation 3, 51-76.

OECD (1994), Insurance Statistics Yearbook, 1984-1991. Organization for Economic Co-operation and Development, Paris.

Park, Cheol (1995), "Monitoring and Debt Seniority Structure." Working paper, University of Chicago.

Pennacchi, George (1988), "Loan Sales and the Cost of Bank Capital." Journal of Finance 43, 375396.

Persons, John (1995), "Liars Never Prosper? How Management Misrepresentation Reduces Monitoring Costs." College of Business Working Paper 95-4, Ohio State University.

Rajan, Raghuram, and Andrew Winton (1995), "Covenants and Collateral as Incentives to Monitor." Journal of Finance 50, 1113-1146.

Ramakrishnan, Ram, and Anjan Thakor (1984), "Information Reliability and a Theory of Financial Intermediation." Review of Economic Studies 51, 415-432.

Roe, Mark (1994), Strong Managers, Weak Owners: The Political Roots of American Corporate Finance. Princeton University Press, Princeton, NJ.

Sahlman, William (1990), "The Structure and Governance of Venture Capital Organizations. "Journal of Financial Economics 27, 473-521.

Saunders, Anthony, and Ingo Walters (1994), Universal Banking in the United States: What Could We Gain? What Could We Lose? Oxford University Press, New York.

Stein, Jeremy (1995), "An Adverse Selection Model of Bank Asset and Liability Management with Implications for the Transmission of Monetary Policy." NBER Working Paper No. 5217.

Williamson, Stephen (1986), "Costly Monitoring, Financial Intermediation, and Equilibrium Credit Rationing." Journal of Monetary Economics 18, 159-179.

Winton, Andrew (1995a), "Costly State Verification and Multiple Investors: The Role of Seniority." Review of Financial Studies 8, 91-123.

Winton, Andrew (1995b), "Delegated Monitoring in a Finite Economy." Journal of Financial Intermediation 4, 158-187. 
Table 1: Sequence of Events

O Time 0:

Firm needs funds. Manager issues debt, equity to investors.

Institution monitors (at positive cost) with some probability.

O Time $1 / 2$ :

If institution monitored, find out whether firm will succeed or fail at time 2 .

Institution may face liquidity need, can seek funding.

O Time 1: If institution has control, can liquidate firm.

Manager can make counteroffer to try to stop liquidation.

If no liquidation, manager gets nonpecuniary control benefit.

Time 2: If firm not liquidated, firm succeeds or fails.

Contractual payments made to institution. 